\title{
Breve fra Gustav Johannsen til A. Regenburg.
}

\author{
Ved H. F. Petersen.
}

Den 2. August i Aar fejrer vi Hundredaarsdagen for Gustav Johannsens Fødsel. Foruden meget andet var han ogsaa Medstifter og Medudgiver af Sønderjydske Aarbøger. $\left.{ }^{1}\right)^{\text {. }}$

Der er i Aarenes Løb, særlig af Familien, udgivet en Del til Belysning af G. Johannsens Liv og Gerning. Men da man ikke hidtil har kunnet følge ham i hans første Man'ddom's Virke i Aarene lige efter 1864, gengives her en Samling utrykte Breve fra ham til A. Rege nburg. ${ }^{2}$ ) Brevene beror i Rigsarkivet.

Gennem de foreliggende Breve faar vi Adgang til at folge Gustav Johannsens personlige Udvikling især før 1881, da han begyndte sin parlamentariske Virksomhed og blev kendt videnom. Samtidig gives os et Indblik i Tidshistorien, som supplerer de allerede udkomne Breve fra J. P. J u ng gree ${ }^{3}$ )

Det var i 1855, Gustav Johannsen og A. Regenburg saas første Gang. Sidstnævnte, der den Gang var Departementschef $i$ det slesvigske Ministerium, var kommen til Treja Sogn for at se, hvorledes Sprogreskriptet virkede i de sydligste Skoler. Ved Afrejsen fra Sylvested Skole udtalte han for Sognepræsten, C. P. B rasen, at hvis han kunde gøre noget for Lærer Johannsens Søn Gustav, der i Skolen havde vakt hans Opmærksomhed, vilde han gøre det med Glæde.4)

Gusta v J oh annsen saa Dagens Lys i 1840 i Gundeby Lærerbolig, Llsnæs Sogn, ved Slien. Hans Bedstefader, Johann Friedrich Johannsen, var fodt i Skæggerød, Nørre Brarup Sogn i Angel, i 1751 og dode sammesteds i 1819 efter at have været Larer i Skæggerød i 51 Aar. Han var især matematisk begavet og fik en Kaldelse som Matematiker til Sachsen, men tog ikke imod den, fordi hans i 1778 i Dollerødskov, Sønder Brarup Sogn, fødte 2. Hustru ikke kunde Tysk. 
Selv var han dansksindet, men maatte jo kun undervise paa Tysk, saa hans Søn, Burchardt Friedrich Job a n n èn, kun kunde Sønderjydsk og ikke uden videre kunde paatage sig at undervise paa Dansk. Han blev født i 1803 i Skæggerød. Fra 1819 til 1864 virkede han som Lærer forskellige Steder i det sydlige Slesvig: til 1823 som Elementarlærer ved V'ilhelmineskolen i Slesvig By, 1823-25 som Larer i Lyrskov, 1825-30 i Lille Rheide, Krop Sogn, Syd for Danevirke, og 1830-41 i Gundeby. $\left.{ }^{5}\right)$ Den 23. Sept. 1830 viedes han i Haddeby Kirke til A nna Catharina Jøns (1809-93).

Foruden en Datter, som døde som ganske lille, fødtes $i$ Egteskabet tre Sønner, som alle blev Larere. Heraf er Gustav Heinrich Jøns Johannse 1 , den senere Rigsdagsmand, den yngste. Da Faderen i 1841 forflyttedes til Sylvested og blev der indtil 1864, kom Gustav Johannsen til at henleve sin Barndom der.

Lærerhjemmet i Sylvested var et vaagent $\mathrm{Hjem}$, baade nationalt og kristeligt. Faderen tog livlig Del i Tidens Rørelser efter 1830, som han fulgte gennem "Altonaer Mercur". Efter at have overværet den første slesvigske Stænderforsamlings Aabning i 1836, holdt han ogsaa Standertidenden, der var trykt paa baade Tysk og Dansk.") Moderen kunde og vilde kun tale Plattysk, som hun var opvokset med, skønt hun elskede Dansk. Efter Moderen arvede Sønnerne deres Sangstemme og Kærlighed til Musik. Faderen var med til at stifte en Lærerforening og en Læseforening; desuden var han flink til at hjælpe Beboerne med deres Købekontrakter, Testamenter og Skrivelser til Myndighederne. Degnen i Treja kaldte ham derfor spottende "Den Sylvesteder Advokat».

Den lille Gustav skildres som et dejligt Barn med røde Kinder, klare brune Øjne og lysegule Krøller, dertil et frejdigt, tillidsfuldt og vindende Væsen, men hans egen Erindring gaar kun tilbage til 1848. Den 25. Marts det Aar var hall sammen med sin Moder og sine Brødre til Dommarked i Slesvig. Ved den Lejlighed oplevede han at se en Kone forfulgt for sin 
Danskhed løbe gennem Gaderne, medens en stor Skare hujede og skreg og kastede med Sten efter hende. Dette var hans første Barndomsminde.

Snart skulde han opleve Krigen paa nært Hold. Dagen efter Slaget ved Bov (9. April) drog en Afdeling Friskaremænd, mest Kieler Studenter, gennem Sylvested, men allerede Dagen derpaa kom der dansk Indkvartering. Palmesøndag den 16. April konfirmeredes hans ældste Broder Johannes i Treja Kirke, medens danske Soldater holdt Vagt udenfor. Efter Paaskeslaget ved Slesvig drog de danske Tropper bort, og der kom nu en Trængselstid for de dansksindede Beboere. Faderen skulde arresteres af en slesvig-holstensk Patrulje, og Moderen, som ikke vilde røbe hans Skjulested, blev skældt ud, knubset, trukket i Haaret, ja, spyttet paa, medens Drengene saa derpaa. I de følgende Dage - det var lige inden Istedslaget den 25. Juli 1850 - raabte endog tysksindede Dänisches Weib!« og "verfluchtes Weib!« efter hende; Faderen var imens ftygtet til Lille Rheide. Snart kom de Danske igen, og nu lærte Drengene de danske Soldatersange.

De sidste Skoleaar kom Gustav Johannsen til at lære Dansk i Skolen. Det hang sammen med, at Treja blev det sydligste Sogn, der kom med ind under Regenburg-Tillischs Sprogreskript af 4. Marts 1851, hvorefter Undervisningen i Sylvested Skole i Fremtiden skulde være paa Dansk, og der hveranden Søndag skulde prædikes Dansk i Treja Kirke. Lærer Johannsen opdagede nu, at Børnene til Trods for eller paa Grund af deres plattyske Modersmaal havde lige saa let ved at læse og tale Dansk som Højtysk, men at de ikke i fire ugentlige Timer kunde opnaa samme Færdighed i Tysk som hidtil. Han indbød da Børnene til at faa gratis tysk Undervisning om Aftenen, og næsten alle Forældre sendte deres Børn. Resultatet udeblev da heller ikke, idet en af de tilsynsforende Præster kunde udtale: "Naar der i Sylvested Skole eksamineres paa Dansk, er man i en fuldstændig dansk Skole; eksamine- 
res der paa Tysk, tror man sig hensat til en fuldstandig tysk Skole «. $\left.{ }^{7}\right)$

Gustav tænkte altid med Glæde tilbage paa sine 4 danske Skoleaar. De hjalp ham til det, som allerede var begyndt under Treaarskrigen, nemlig til helt at føle sig som Dansk. Ligeledes kom han allerede $i$ de Aar til en fast Overbevisning om Kristendommens Sandhed, navnlig under Paavirkning af Forældrene i Hjemmet og Faderens Religionsundervisning. De bibelske Skikkelser kom til at staa saa levende for ham, at han i ungdommelig Nidkærhed stak Øjnene ud paa Judas i sin illustrerede Bibelhistorie. En Mængde Bibelsprog indprentede sig saa dybt $\mathrm{i}$ hans Sind, at han mange Aar senere Gang paa Gang indflettede dem i sine Taler.

Vinteren 1855-56 - altsaa efter det første Bekendtskab med Regenburg, som er omtalt ovenfor - gik Gustav til Konfirmationsundervisning hos Pastor Brasen, hvis Gudstjenester han i Forvejen flittigt havde besøgt, og hvis Personlighed han satte stor Pris paa. Paa Vej til Præsten deltog han i de øvrige Børns Morskab. Palmesøndag 1856 holdtes saa den første danske Konfirmation i Treja.

Efter Konfirmationen blev Gustav Johannsen Hjælpelærer i Treja og underviste den nederste Klasse med 133 Børn. Da Biskop B o e s e n holder Visitats i Treja den 23. Juni 1858, skriver han i sin Beretning bl. a.: "Især udmærkede sig en confirmeret Dreng baade i Kirken [Biskoppen beordrede altid de 3 sidste Aars Konfirmander til at møde paa Kirkegulvet] og - i Skolen, nemlig Gustav Heinrich Jøns Johannsen, en Søn af Skolelæreren. Han agter at gaae til Seminariet i Tønder i Foraaret 1859, og jeg maa paa det Bedste anbefale ham til at erholde Friplads og Stipendium.«

Provst $\mathbf{A l e t h} \mathrm{Hans}$ en havde ogsaa faaet Interesse for den unge Mand, saa at Pastor Brasen allerede den 29. Juli s. A. kan skrive til Regenburg $\left.{ }^{8}\right)$ : "Bemeldte Gustav Johannsen har erhvervet sig baade Biskoppens og især Provstens Yndest, saa 
at sidstnævnte har kaldet ham til en - vel besværligere - men ogsaa mere lønnende Post ved Hulvejsskolen i Adelby Sogn«. I 1859 var han knyttet til Adelby Skole for saa at tilbringe $5 / 4$ Aar paa Tonder Seminarium og efter Privatundervisning $i$ København at faa Lærereksamen i Efteraaret 1860.")

I November 1860 ansattes Gustav Johannsen saa ved Langballe Skole i Grumtoft Sogn, vel nok det mest levende Sogn i hele Angel. Her blev han, indtil han blev afsat af Tyskerne $i$ 1864, og det blev en lykkelig og frugtbar Tid baade for ham og hans unge Hustru. Den 5. Januar 1862 blev han nemlig gift med Margaretha $K$ ühl fra Treja. Hun tilhørte en velhavende Storbondeslægt og medbragte en ikke ubetydelig Medgift, som kom til at spille en vigtig Rolle i senere Aar, da Indtægterne svigtede.

Han var den fødte Lærer, der straks vandt Børnene for sig: straalende af Humør, varm og livlig, opfindsom og i Besiddelse af en glimrende Fortælleevne; ikke sært, at Undervisningen gik med Lyst. H. P. Ha n s s e n har en Gang ${ }^{11}$ ) skrevet om G. Johannsens Langballe-Tid: "Hvor hyggeligt er ikke Billedet af den unge Skolemesters lykkelige Hjem i Angel. Ingen Lærer i hele Angel, sagde en af hans daværende Nabolærere en Gang til mig, "havde smukkere Stuer og en smukkere Kone«. Han burde have tilføjet: Og ingen Lærer $i$ hele Angel stod mellem Krigene $i$ et smukkere Forhold til den vanskelige, mistænksomme Befolkning dernede. End ikke Angelboerne kunde modstaa Gustav Johannsens Elskværdighed. Ogsaa dernede gik han, som en af hans Venner en Gang har sagt med et djærvt Ord: ud og ind ad Folk med Træsko paa. Og iog var han sig selv, dansk til Liv og Sjæl. En Dag, Aaret før sidste Krig, foretog han en Udflugt til Dybbøl med sine Skoleborn. Omtrent Halvdelen var fra tysksindede Hjem. Deltagelsen var frivillig, men ingen havde holdt sig tilbage. Med Dannebrog i Spidsen og syngende danske Fædrelandssange gik Turen forst til Stranden, hvorfra de sejlede over til Sønderborg. Om Aftenen kom den lille Trup tilbage i straalende Humør 
efter at have tilbragt en prægtig Sommerdag paa de minderige Steder. Forældrene, týske saa vel som danske, stod ved Landgangsstedet og tog imod dem. Og mens danske Sange tonede ud over den stille Fjord, var al Modsæetning som bortblæst. I sine sidste Aar betegnede Gustav Johannsen ofte den Dag som en af de dejligste, han havde oplevet."

Udenfor Skoletiden samlede han de voksne Unge til Undervisning i Dansk og deltog i Folkefesterne paa Egnen. Den danske Lærerforening i Angel valgte ham til Sekretær. Med mange i Befolkningen knyttede han Forbindelser, der varede Livet ud.

Da kom Tilbagetoget fra Dannevirke i 1864 som et forfærdeligt Slag. Ud paa Natten vaagnede Fru Johannsen ved sin Mands heftige Graad. Store Taarer randt ned ad hans Kinder. Han græd over Danmarks Ulykke. Det varede ikke længe, inden han selv blev jaget fra Hjem og Gerning. Hvad skulde han nu? Søge sig en Lærergerning i Danmark som hans Brødre eller gaa fra Lærergerningen og stille sig i sit Folks Tjeneste i Sydslesvig? Længe vaklede han, men tilsidst valgte han at blive paa Skansen, saa dygtigt, at der i 1899 kunde udtales om ham i den tyske Rigsdag: "Det var unægtelig Hr. Johannsen, der i 1865 langsomt fik Folk i Slesvig sat i Bevægelse paany. Han holdt allerede den Gang en vidt forgrenet Agitations Traade $i$ sin Haand. Til den ene Side naaede denne Agitation til København, til den anden til den augustenborgske Lejr «. ${ }^{11}$ )

Det er om denne den 24-aarige Landsbylærers første vækkende Indsats i Folkesagens Tjeneste, nedenstaaende Breve handler. I Brevene er foretaget enkelte Udeladelser af ikke henhørende Ting. Retskrivningen er næsten overalt forandret ti) Nutidssprog.

Mit Haab er, at jeg ved Fremdragning af disse Breve kan yde et Bidrag til Forstaaelsen af Gustav Johannsen som den "Mand uden Frygt og Dadel", der altid vil huskes som Sønderjydernes stovte Fører. 
Flensborg, 27. Maj 1864:

Man vil vinde mig for Anneksionen [med Preussen]. Kamjnerjunker v. Bertouch skal søge at fange mig. Som Lokkemiddel vil man forst og fremmest give mig Tilladelse til ugenert at forfølge det augustenborgske Parti.

Skal jeg spille den falske, og er det rigtigt at hjælpe Preussen til at faa Augustenborgerne ganske og aldeles udryddede. Kan jeg vente at faa en lille Rejseunderstottelse, naar jeg med første Lejlighed tog til København for at faa Parolen?

Maa jeg bede Etatsraaden om godhedsfuldt at svare mig paa disse to Sporgsmaal, om ogsaa kun "ja " eller "nej«. Disse Ord skal være mig nok.

p. t. Øster Ulslev [paa Lolland hos Broderen Thomas]:

I Morgen tager jeg til Flensborg for at bosætte mig der, og skal jeg ikke undlade fra Tid til anden at meddele Deres Højvelbaarenhed et og andet derovre fra. For ikke at vække Mistanke har jeg efter Provst Hansens Anmodning bedt min Broders Svoger, Malermester Hansen i Gothersgade 89, om at modtuge og besørge mine forseglede Breve til Dem.

Flensborg, 5. Nov. 1864 (Adr. Købmand Partsch i Hulvejen):

I Søndags ankom jeg hertil med Dampskibet "Diana«. Førend vi ombordværende Passagerer kom i Land, blev vore Rejseeffekter eftersete af to unge Toldbetjente. Formanden for Litzenbrodrene - en Th a is en fra Hulvejen - kendte mig, og da jeg undrede mig over det forandrede Flensborg, raabte han ganske højt ud til mig: "Det er ikke mere som før, Hr. Johannsen, men det kan blive godt igen!« Straks lettede en Del Flensborgere, som stod paa Dampskibsbroen, Hatten og spurgte mig om gode Tidender.

Hos Værtshusholder Thomas Andresen i Norden sang nan "Den tapre Landsoldat«, "Der er et yndigt Land" osv. Flensborgerne er endnu ved godt Mod, selv omgiven af Preusserne udtaler man den Mening, at "Enden vil blive god «.

Den 31. om Morgenen hørtes Kanonsalut, som den berygtede 
K o r f-P e t e r s e n - Lappedose kaldet - lod affyre i sin Glæde over Fredsinstrumentets Undertegning, ogsaa hejsede nævnte Herre et Oprørsflag paa Skibsbroen, og alle tysksindede, selv nogle enkelte ængstelige Loyale, flagede. I Norden saa man kun hist og her et Flag, i Smaagaderne næsten ingen, og ovenfor Havretorvet atter ganske faa.

Da jeg samme Dag var gaaet ud for at leje en Beboelseslejlighed, blev jeg af Degn Tofte ved den danske Kirke vist op til den nye danske Præst, Karstens [ikke at forveksle med den senere Pastor H. J. Carstens], som havde en ledigstaaende Lejlighed. Vi kunde imidlertid ikke komme overens om Lejen, da jeg kun vilde bo sammen med Præsten, naar jeg kunde faa Lejligheden meget billig. Imidlertid fik jeg dog Lejlighed til at forny mit gamle Bekendtskab med Hr. Karstens. Han mente, at jeg, som Slesviger, nok om nogen Tid kunde komme i Betragtning ved Besættelsen af et eller andet ledigt Skolelærer-Embede, men da jeg ganske rolig svarede: "Jo, jeg haaber, at jeg om kortere eller længere Tid atter vil blive ansat som Skolelærer i Slesvig, og det skal være mig en Glæde atter at kunne virke $\mathbf{i}$ niit Kald«, mærkede han, hvorledes jeg tog Tingen, og - ich wurde entlassen! [Audiensen Slut.]

Om Aftenen skulde der illumineres, men da man pr. Telegraf havde faaet Parolen fra Kiel, blev det ikke til noget, kun Crastgiver Storm i "Stadt Kopenhagen" og et Par andre uvidende brændte den Aften deres Lys i Vindueme. M a n e r i k ke tilfreds med Freden.

Gaardmand Christiansens Søn fra Kollund, Bov Sogn, fortalte mig sidst, at mange af Kollund'erne slet ikke sendte deres Børn i Skolen, da de ikke vilde have dem germaniserede af den nye Lærer. Ligervis gaar det i Vejbæk, Harrislev o. fl. St. I Hanved synger man endnu "Den tapre Landsoldat«. Folk fra Flensborgs Omegn, der har Raad til at betale for deres Børn, sender dem i den danske Borgerskole.

I Forgaars bragte "Itz. Nachr.« et Telegram fra København, hvori det hed, at alle afsatte slesvigske Embedsmænd skulde 
pensioneres fra Slesvig. Denne Efterretning bragte Tyskernes Blod til at koge. Jeg hørte saaledes en Mand fra Munkbrarup paastaa, at han kendte »æ Wühlere«, som var Skyld i »æ Præsts og æ Diens« Fjernelse fra deres resp. Embeder, og han - Manden - og flere var enige i ikke at betale til Pensionen, men tværtimod vilde de anklage »æ Wühlere« og bringe dem til at betale for hele Sognet. Jeg gød Olie i Ilden, og Manden vil nu nok faa Sagen i Gang, saa det kan blive en stærk Modvægt for Agitationen i Munkbrarup og Omegn. Ogsaa i Grumtoft Soyn vil man ikke længere følge Agitatoreme; ja, Nis Lorenzen i Langballe har endogsaa anklaget nogle unge Folk, der sang "Schleswig-Holstein" forbi hans Hus.

I Flensborg har man beregnet, at Slesvig vilde komme til at betale 500,000 Rigsdaler i aarlig Pension til de afsatte Emhedsmænd, hvorover Tyskerne er grumme flove. De dansksindede mener, at Slesvig nok bliver ved Danmark, saa der ikke hliver Tale om Embedsmændenes Pensionering, men derimod om deres Genindsættelse. I Dag siges der, at flere holstenske Adelige er ankomne hertil for at overbringe [Civilkommissær] Z edlitz en Adresse, hvori de udtaler, at de ikke vil under Preussen, men hellere under Danmark. Mange tysksindede omvendes i disse Dage, thi "den daarlige Fred«, som Tyskerne siger, er den danske Agitation gavnlig.

Provst $P$ eters her $i$ Byen forfølges baade af dansk- og tysksindede. Man undlader at bruge ham ved alle mulige kirkelige Handlinger, og Bladene river ned paa ham. Degn K a rstens i Grumtoft, Pastor Karstens' Fader, har indgivet sin Ansøgning om Entledigelse fra sit Degneembede, thi han indser, at Tragedien lakker ad Enden, og han vil dog gerne slippe saa heldigt som muligt. Ogsaa der er mange, som venter paa Danskernes Genkomst og derfor holder deres Børn hjemme, idet de helst vil "ha' dem i æ Skol ved en dansk Lærer«.

Tyskerne kan heller slet ikke forstaa, hvorfor jeg er vendt tilbage, de tror at se et slemt Varsel for Tyskheden i min Tilbagekomst. Naar jeg ganske frejdigt siger til dem: "Nu kommer 
Danskerne igen ", faar jeg altid det mismodige Svar: "De' ka æ se«. Slagter G. Parts ch ved Havretorvet tordner endnu som altid for de tyske Angelboere, og mange er fornuftige nok til at folge hans gode Raad. Min Fader, som i Dag er i Besøg hos mig, fortæller, at en Mand fra Sønderborg paa Jernbanen fra Slesvig hertil havde paastaaet, at Folkene i Sønderborg, Als og Sundeved endnu ikke havde lidt nok under Krigen, thi endnu var de fanatisk danske. Preusserne er ogsaa ked af "Schleswig-Holstein". En preussisk Officier sagde saaledes til Fader, at "Schl.Holst." var nogle utaknemlige og for det meste udannede Folk. Han - Preusseren - havde ligget i Kvarter hos Præsten i Treja, men havde slet ikke haft det godt. Præsten havde sagt ham, at han onskede Preusserne hjem. Derimod var Skovrideren i Treja - en Dansker - den pæneste og mest dannede Mand. Saaledes gaar det nu i disse Tider: Man er ked af Preusserne. Gud give, at det gamle Dannebrog snart igen maa indtage Oprørsflagets Plads!

Flensborg, Sønder Hulvej Nr. 992, 5. Nov. 1864: I Dag bringer et Telegram til "Nordd. Zeitung" den Efterretning, at "de for Tiden i Hertugdømmerne liggende fremmede Tropper skal vende hjem og andre indtage deres Plads, da der muligvis snart vil indtræde en Forandring i Hertugdømmernes Stilling «. Gæstgiver Dodt i Rødegade forklarede dette Telegram saaledes for sine Gæster: „De tyske Tropper vender hjem, russiske, svenske eller andre Tropper kommer og indtager deres Plads, og om et halvt Aars Tid kommer vore danske Brødre igen, og Dannebrog indtager sin gamle Plads«. Gæsterne syntes godt om den Forklaring og udtalte deres Ønske om Danskernes Genkomst.

Degn Petersen s Søn fra Egebæk ytrede i Dag til mig, at Slesvig hellere vilde taale et materielt end det tidligere aandelige Tryk. Den gamle Fader, der før hyklede for sine danske Foresatte, har nu kastet Masken og er bleven en ægte "Schl.Holsteiner«, og Sonnerne følger hans Eksempel. 
6. Nov.: I Formiddags var jeg i den danske Kirke og hørte Karstens prædike. Der var mange Tilhørere, og man sang og priste Gud i det dejlige, danske Sprog saaledes, at man hørte, Sangen kom fra Hjertet. Dannebrog hænger endnu urørt i dette Guds Hus. Rygtet taler i Dag stærkt om, at der kommer Fussere hertil, og de dansksindede er saa glade derover, at jeg endog har hørt dem sige, at de gerne vilde lære Russisk, naar dette kunde blive en Overgang til deres kære Dansk. »Dansken maa komme igen, om vi ogsaa selv skal hente ham «, siger Flensborgeren. Jeg tror, de gjorde Oprør, hvis det kom saa vidt, at Slesvig kom under Hertugen, og kom det under Preussen, saa vilde "Schl.-Holst." hjælpe til at afkaste det fremmede Herredømme. - K or f-P e t e r s e n - Lappedose kaldet - har maattet betale 50 preuss. Dalere i Mulkt, fordi han uden Tilladelse-lod salutere i Anledning af Fredsinstrumentets Undertegning. Den bekendte Funk e har ogsaa maattet betale en stor Mulkt, fordi han tændte Blus i samme Anledning. Teglværksejer $\mathrm{M}$ a d s en $\mathrm{i}$ Egernsund er bleven arresteret, fordi han viste sig altfor slesvig-holstensk, hvorover Tyskerne er meget forbitrede. En Handelsbetjent, $P$ a uls en fra Heide, udbragte i Gaar Aftes i et Selskab, hvor der var Preussere til Stede, en Skaal for Hertugdømmernes "ewig Tosammenbliwen mit Dänemark«. Selskabet modtog Skaalen med Jubel, og Preusserne stemmede i med.

7. Nov.: I Dag har jeg været i Grumtoft, Dollerup og Langballe. Dannebrogsmand Hinrichsen i Dollerup bad mig om at skrive til København, at han og flere Hundrede Angelboere gerne vilde følge Nordslesvigernes Exempel og sende en Adresse til Kongen, naar det kunde være til Nytte. Han har i Sinde at ansøge hos Zedlitz om Tilladelse til at genoprette den angelske danske Læseforening. I Smug holder de dansksindede dersteds endnu altid Sammenkomster, skønt. Tyskerne er slemt efter dem. Fredsartiklerne har ellers virket nedslaaende baade hos Danskerne og Tyskerne. Mange dansk- 
sindede har sagt mig, at de, hvis Slesvig kom fra Danmark, vil sselge deres Ejendom og tage til Danmark; mange paastaar, at Københavnerne har solgt os, at de aldrig har holdt af os, at de hellere selv vil leve i Fred og Ro end med os kæmpe for Danmark og den danske Sag. Derimod er der andre dansksindede, som taler om, at vi først maa høre Leen og Jerntyven synge, førend det bliver godt. Der er dem, som er rasende og lader deres Raseri gaa ud over enhver Tysker, de træffer sammen med. Ogsaa det gaar i denne Tid. Men stakkels, stakkels Slesvig! hvornaar vil det blive bedre?

8. Nov.: I Dag tales der om, at Preusserne snart vil tage det unge slesvigske Mandskab til Soldat. Tyskerne er fortvivlede over dette Rygte, og Danskerne paastaar, at de nok vil blive fri; thi de tænker paa de forste 5 a 6 Aar at holde Preusserne hen med den Erklæring, at de vil gaa til Danmark. De paastaar, at Kongen ikke ene kan løse dem fra deres Ed; thi naar en Ed skal hæves, skal begge Parterne være enige om at hæve den, og de vil aldrig tage deres Ed tilbage. Saa fast holder man ved Kongen, at man siger: whan er nødt til at frisige os fra Eden, men os kan ingen tvinge til at opgive den«. De vestfalske, pommerske og slesiske Preussere gik gerne med de dansksindede, naar det atter kom til Krig.

9. Nov.: Næsten hver Dag har jeg Besøg af dansksindede Folk fra Landet, navulig fra Angel. De gode Folk vil hente Trøst og Opmuntring hos mig, og jeg ved tit og ofte ikke, hvormed jeg skal troste og opmuntre dem. Bare jeg vidste noget! tænker jeg tit; men hvad jeg ved, ved andre ogsaa. Der er ingen, der har tabt Troen paa Danskernes Genkomst, men man kan ikke forstaa, hvorfor det varer saa længe. Folk, som før hverken var det ene eller det andet, er nu saa dansksindede, som man kan forlange. Den danske Sag har aldrig staaet bedre i Slesvig end i denne Tid. Jeg tænker tit paa, hvor let det var at bringe Folk til at gøre Oprør og selv kaste Aaget fra deres Skuldre; men vore 
Slesvigere haaber jo, at det af sig selv vil blive godtigen. Tyskerne tror noget lignende, det kunde jeg høre af Købmand Jensen i Norden, der er en agte Tysker.

10. Nov.: Krigsassessor J u h l fra Sterup fortalte mig i Dag, at hans Ekscellence, Minister Joh a n $\mathbf{J}$ s $n$, havde sagt til ham, at han nu godt kunde soge Kald her i Slesvig, og det lod til, at han ogsaa tænkte paa at benytte sig af denne indirekte Tilladelse. Mon hans Ekscellence virkelig har sagt saaledes, og mon det er den høje Regerings Mening, at vi afsatte slesvigske Embedsmænd atter skal lade os ansætte af den fjendtlige Regering? Skulde vi nu tage imod Embeder og hjælpe til at udrydde Danskheden og det danske Sprogi Slesvig? Nej, det er for meget forlangt, da var man jo ikke værd at kaldes en dansk Mand, og det kan heller slet ikke være vor høje Regerings Mening, tænker jeg. Kan vi ikke hjælpe os selv, og alle Mennesker ikke hjælpe os, saa kan dog Herren endnu altid knuse Fjenden i sit Overmod, og jeg stoler fast paa og forkynder mine Trosfæller: Gud han raader, naar vi fange Sejr igen!

11. Nov.: Den danske Slesviger kan dog altid finde Trøst i sin Nød! Saaledes paastaas der i Dag, at Kejser Na p o l e o ikke er tilfreds med Freden, men at han vil have, at Slesvig skal deles ved Flensborg, og den Del, der ligger Norden for Flensborg-Linjen, skal uden videre indlemmes i Danmark; hvad der ligger mellem Flensborg og Dannevirke, skal have Afstemning, og det ovrige Slesvig indlemmes i Holsten og ved Personalunion forenes med Danmark. Gid det maatte ske saaledes!

I Adelby Sogn tvang man forleden Præsten til at døbe paa Dansk, og Degnen, den tyske Schlesinger, maatte, hvor nødig han end vilde, synge Dansk. Dette fortalte jeg i Formiddags til Pet er Hansen fra Bygbjerg, hvorover han blev meget glad; thi nu vilde han forlange den hellige Nadver uddelt 
i dette Sprog, da han, saa længe Grumtoft har haft dansk Kirkesprog, altid har gaaet til dansk Altergang, og da han bedst forstaar og taler Dansk. Han sagde, at han var vis paa, at flere vilde følge hans Eksempel. Jeg fandt det ogsaa rigtigt; thi mange i Grumtoft Sogn forstaar ti Gange bedre Dansk end Tysk. "Gud give, vi snart igen maa faa vort eget Maal!" er et almindeligt Ønske hos de dansksindede i Grumtoft. I den tyske Sangforening her i Byen har der i Aftes fundet et Sammenstød Sted mellem Foreningens Medlemmer og en Del preussiske Officerer. Sidstnævnte paastod, at der ikke eksisterede noget "SchleswigHolstein«, hvorover førstnævnte blev meget irriterede. Det skal endogsaa være kommen til Haandgribeligheder.

12. Nov.: Stemningen i Slesvig er, som ovenfor sagt, meget god, og Tyskernes Slethed bidrager ikke lidet til at vedligeholde og opfriske det danske Sindelag hos Slesvigs loyale Befclkning. Derimod skader det kongerigske ægte liberale eller "Dagbladet«s Parti ikke lidet ved dets Udtalelser om Hans Majestæt Kongen og vore Ministre. Saaledes har forleden en fordreven slesvigsk Præst skrevet til en dansk Mand i Angel og udtalt sig ufordelagtigt om en højtstaaende Person, hvilket ikke har været uden skadelig Indflydelse paa vedkommende. Det kunde være gavnligt, om de fordrevne slesvigske Embedsmænd af og til vilde tilskrive en eller anden blandt Folket herovre, men de maa paa ingen Maade skrive i ovennævnte Retning. Der er mange, som klager over deres fordrevne Foresattes Ligegyldighed mod dem, som de ellers omgikkes. Dette kunde og burde forebygges.

I Sterup Sogn virker tidligere Sandemand Carstensen paa det kraftigste for den danske Sag, og mange følger ham. - Jeg fortalte ovenfor, at det sidst var kommet til Rivninger mellem de tysksindede af Sangforeningen og Preusserne. Dette gik saaledes til: Redaktør $\mathrm{Herzbruch}$ holdt først en patriotisk Tale og stødte derved Preusserne. Saa stod en dansksindet op og holdt en Tale, hvori han sagde, at Flensborgerne hid- 
til havde faaet deres daglige Brod ved Samkvem med Danskerne, hvilket bestredes af Tyskerne, der i deres Iver udbragte Prætendent Friedrichs Skaal; men førend den rigtig blev udbragt, begyndte den preussiske Musik at spille den preussiske Nationalhymne. Nu blev Redaktør Herzbruch bister og tog en Flaske og kastede med den efter Preusserne, og saa var Sagen i fuld Gang. Herzbruch har været hos Kommandanten for at bede om Forladelse, men denne har slet ikke villet tale med ham. Videre er Sagen endnu ikke kommen.

Man har i disse Dage uddelt smaa Bøger, som skal bevise, at Hertug Friedrich slet ikke duer til Regent i Hertugdømmerne, men at derimod Storhertug P eter fra Oldenburg er den rette Mand. Hertug Friedrich bliver skrækkelig nedrakket i disse Smaaskrifter. De er imidlertid allerede forbudte af Civilkommissærerne. $\mathrm{Og}$ saa var de kun bestemte for Bønderne, hed det, da Bevisførelserne var daarlige. Bare dygtig fremad paa den Vej, saa gaar Schleswigholsteinismen forst rigtig sin Undergang i Møde! Hele Slesvig er fuld af det Rygte, at Preussen gerne vil af med os igen, vi skal bare selv hjælpe til. Bliver dette først levende for Folket, saa kan vi snart vente mange interessante Demonstrationer.

27. Nov. 1864: Da min kære Kone den 18. dennes nedkom med en lille Datter [Alexandra], har jeg ikke før faaet Tid til at skrive til Deres Højvelbaarenhed. Her i Flensborg gaar alting sin vante Gang; de dansksindede udbreder stadig gode Tidender, der af den lettroende bliver holdt for gode Varer. I den forbigangne Uge har man haft travlt med at fortælle om Russernes Ankomst til Sverrig. Slesvig-Holstenerne er bange for de "lumske og egennyttige Preussere», som de kalder dem. Der finder idelige Sammenstød Sted mellem Preusserne og SlesvigHolstenerne; men Preusserne gør kort Proces med de oprørske Slesvig-Holstenere, og man hører ikke saa sjældent, at en eller anden bliver straffet for antipreussiske Udtalelser.

I Treja har man slaaet en preussisk Soldat ihjel, og her i 
Flensborg har man saaret et Par. En preussisk Feltpræst har forleden erklæret Slesvig Holstenerne for et ugudeligt Folk, hvilket har vakt stor Forargelse i »det frihedselskende SlesvigHolsten «. Da Preusserne forleden forlod Aabenraa og intet Militær var i Nærheden, slog man Hjemmetyskernes Vinduer ind. Det var "Tak for sidst《. Mange preussiske og astrigske Officerer paastaar, at Kong Christian atter vil blive Herre over Hertugdommerne. Saadanne Talemaader opmuntrer de dansksindede, men nedstemmer Hjemmetyskernes Overmod.

Den før fordrevne Pastor Volquarts her fra Byell skal nu komme tilbage hertil. Der har været en Deputation af Volquarts Tilhørere hos $Z$ edlitz og bedt ham om at gøre Volquarts til Provst; men Zedlitz har svaret: Peters er og bliver Provst, og Volquarts kan være glad til, at han er bleven Præst igen. Boghandler Herzbruch er ikke længer Redaktør af "Nordd. Zeit.", derimod har Advokat $\mathrm{R} ø$ m e r overtaget Redaktionen af nævnte Blad.

Det jammerligste af alt herovre er dog Embedsstanden; den er saa daarlig, at selv tysksindede kan indse det. Folk har hverken Agtelse eller Respekt for deres Øvrighed, ja, forleden sagde $\mathrm{Th}$ omas Feddersen i Sylvested, at han ikke brod sig om at gore, som han lystede, thi Øvrigheden havde hverken Kraft eller Vilje til at styre de undergivne. Det er ikke blot de dansksindede, men ogsaa Tyskerne, der river ned paa Embedsmændene. Stadig onsker man de fordrevne Embedsmænd tilbage og roser deres Dygtighed. I Gottorp længes man efter Kancelliraaderne $\mathrm{Knudsen,} \mathrm{Mohns} \mathrm{og} \mathrm{B} \mathrm{la} \mathrm{uen-}$ feldt. Alle Vegne finder man dansksindede, og næsten i enhver Landsby er der en eller anden Mand, og det ansete og agtede Mænd, der holder. den lille Flok sammen og opmuntrer dem til Udholdenhed. Saaledes D. M. R a t $\mathrm{b}$ je i Sylvested, den afsatte Bondefoged i Schubye, D. M. Krøger i Dannevirke, He n z e $n$ i Treja, D. M. P $1 ø n$ i Hollingsted, D. M. A n dresen i Derpsted, Hagge i Ellingsted, Si erk i Krop, Henzen i Brekendorf, Boch sens chmidt i Jybæk o. s. v. Alle 
disse virker paa det ivrigste, baade i Stilhed og aabenlyst, for den gode Sag. I Brekendorf er især en fast Stok af danske Mænd. Markeligt er det, at hele Stapelholm holder sig rolig i disse Tider; der er nok en eller anden Agitator, men Flertallet er roligt. Embedsmandene i Byen Slesvig, navnlig Landsforræderen, Amtmand J a k o b s n, har faaet en Irettesættelse for deres Embedsførelse, og det lader til, at denne Irettesættelse allerede har frugtet.

I Nordslesvig havde man begyndt med at lade Drengebørnene udskrive af Lagdsrullen, men da der kom for mange, mente Herredsfogderne, at de ikke kunde vedbive at tilfredsstille Folkets Ønsker i saa Henseende, førend de havde indhentet Civilkommissærernes Tilladelse. En Del af de hjempermitterede Preussere skal være kommen tilbage til Als og Sundeved for at søge Arbejde der og for, hvis Preussen atter skulde føre Krig, at kunne slippe bort til Danmark. Paa mange Steder venter man paa den forste Skatteudskrivning, og det er disse ventendes Bestemmelse ikke at betale til nogen anden end den danske Regering. Man siger ogsaa, at Kong Christian endnu kalder sig Hertug til Slesvig, Holsten og Lauenborg, og man slutter deraf, at den danske Regering endnu er den rette i de nævnte Provinser. Daglig gaar store Afdelinger af den fjendtlige Har sydpaa, og da en gammel Spaadom siger, at Preusserne skal komme og gaa bort i Sne og blive fulgt af Danskerne, glæder man sig meget over og stoler paa, at Spaadommen i alle Maader vi gaa i Opfyldelse, da det i disse Dage har sneet. Er det ogsaa uforstaaeligt, hvor Folk kan finde paa saa meget, saa er det dog et Bevis paa, at Slesvig er dansk, og at Slesvigerne foler sig bunden til Danmark. Har ogsa a 1 t forladt Slesvigeren, Troen paa den gode Sags Se j r har i k k f orlad t ham. Rygtet siger i Dag, at Preusserne har haft et Sammenstød med Forbundstropperne i Holsten. De her liggende Preussere rykkede ogsaa ganske pludselig ud i Eftermiddags Kl. 4, og et Batteri, der skulde blive her til i Morgen, fik ligeledes i Eftermiddags Marchordre og er alle- 
rede borte. Her er stor Glæde over dette Rygte, og Preusserne siger: Enden er endnu ikke kommen. Saa meget er nok afgjort, at Preussernes Bortmarch er sisteret. Ogsaa siger man, at Danmark, Sverige-Norge og England atter vil optage Krigen med l'reusserne.

Jeg har i denne Tid faaet nogle Privattimer hos Grosserer P. S chmidt og B oysen, et Par dansksindede Folk, som ikke vil lade deres Børn bruge Latinskolen. Det kommer nu kun an paa, om Visitatoriet for Byen Flensborg ikke forbyder mig at læse med disse Børn. Uden Bifortjeneste kan jeg heller ikke leve af min midlertidige Pension, og jeg haaber, at man ikke vil give mig mindre i Understøttelse, fordi jeg tjener lidt til. Var det ikke for den gode Sags Skyld, og fordi jeg haaber, atter om nogen Tid at blive indsat i mit Embede af min kongelig danske Regering, saa vilde jeg onske, at jeg havde et lille Skolehold i det kære Danmark. Et Aar vil jeg gerne virke saa meget, jeg kan, og ogsaa vil jeg gerne lide lidt endnu med mine stakkels Brødre hernede. Bare Haabet vil gaa i Opfyldelse! Men, Gud tager jo ikke sin Haand fra den Troende, og han hjælper jo altid den Svage!

4. Dec. 1864: Det var vist en meget kedelig Skrivelse, jeg sidst sendte Dem; thi jeg skrev den i et Øjeblik, hvor Troen paa den gode Sags Sejr kæmpede med Tvivlen. Gud ske Lov! at saadanne Tvivlens $\emptyset$ jeblikke er sjaldne hos nig, og at det samme er Tilfaldet med mine ligesindede her i Slesvig. Tvivlen kommer, naar man tænker paa Arlskillelsen fra Moderlandet, men naar man saa hører, hvorledes Menigmand bedømmer Situationen, naar man hører ham synge om Slesvig-Holstens falske og Danmarks tapre Sonner, hvilke sidste han lover Slesvigs Genforening med Danmark, saa kommer Troen styrket og fornyet tilbage. Menigmand har da ogsaa en sjælden Force i at dømme i enhver Sag, hvilket jeg sỵnes bevist ved den nylig udkomne Parodi paa den bekendte Vise $O$, Hamnemann! 0 , Hannemann! Wo bleiben deine Länder?" Parodien begynder: „O, 
Mikkelmann! O, Mikkelmann! Wie sitzt du in der Dinte!« Disse og lignende Viser synges af Svende og Drenge paa Gaden og offentlige Steder, uden at nogen krummer dem et Haar, som Flensborgeren siger.

I et Selskab, hvor der var en slesvigholstensk Embedsmand og flere ægte Slesvig-Holstenere til Stede, var jeg Ørenvidne til følgende Scene: Embedsmanden indledede en Skaal med et Par Ord af Schillers »Lied von der Glocke«. Derpaa rejste en indfødt Flensborger og Borger i Byen sig og sagde, at Schiller ikke æredes nok, naar man kaldte ham "unser deutscher Dichter«; thi han var og havde været en Digter for alle civiliserede Folk, for Tyskere og Danskere, ja, selv for Amerikanerne. Han - Taleren - var en Dansker og følte sig som en Dansker, men ogsaa han turde kalde Schiller sin egen Digter. Det var Schiller, som saa tit i sine Digte talte om det højere Væsen, der leder baade det enkelte Individs og Folkenes Skæbne. Det var Schiller, som i sit "Lied von der Glocke« talte om Borgerkrigens Grusomhed, idet han siger: „der Gute räumet Platz dem Bösen [den Gode maa vige Pladsen for den Onde], og »da werden Weiber zu Hyänen" [Kvinderne bliver Hyæner]. Nu vilde han spørge, om ikke den, der tilegnede sig Schillers Ord og fulgte hans Lære, om ikke den - hvad enten han var en Tysker eller en Dansker - hørte med til dem, som i Sandhed tør sige, at Schiller var deres Digter? Havde enhver Slesviger rigtig forstaaet og fulgt Schillers Ord, saa havde det set helt anderledes ud, saa havde ingen Utro turdet rejse sit Hoved, saa havde ingen tro Mand behøvet at frygte i disse Tider. Ja, var blot enhver blevet Menneske og ikke blevet dyrisk, saa kunde de tale om deres Schiller, men nu ikke. I - her henvendte han sig til et Par i Selskabet - er ægte Slesvig-Holstenere, De - her henvendte han sig til Embedsmanden - er en Augustenborger, lad os nu være Mennesker, og drik De, mine Herrer, Deres Hertugs Skaal, og lad mig og mine ligesindede drikke vor Konges Skaal, idet vi siger: Leve Legitimiteten! Ingen svarede, men rolig fortsattes derpaa Samtalen. 
Atter hører man tale om Russernes Komme, og der siges, at Preussen skal have Holsten og Laueuborg, og Danmark faar Slesvig. Man paastaar, at denne Løsning skal vare foreslaaet af Rusland, og at Preussen vil gaa ind derpaa. Preusscrne tror forresten paa en Krig med Forbundet.

I denne Tid holdes der Folketælling her i Slesvig.

4. Januar 1865: Dagen forend den meget bekendte Fredsprædiken holdtes her i Hertugdømmerne, var H. Hinrichs e n fra Dollerup gaaet til Grumtoft for hos Hovedpræsten dersteds at melde sin Søn til Konfirmationsforberedelsen. Hovedprasten, $\mathrm{Hr}$. G o d $t$, sendte Hinrichsen til Diakonus $\mathrm{K} n \mathrm{u} t \mathrm{~h}$, Andenpræst ved Grumtoft Kirke, da denne i Aar har Konfirmationen. Knuth sagde da til Hinrichsen, at Generalsuperintendenten, Hr. Pastor Godt, havde tilsendt Prosterne i Hertugdømmet en Skrivelse, hvori han befalede dem ikke at konfirmere Drengebørn, der var under 15/2 Aar gamle, medmindre der maatte foreligge særlige Grunde. Da imidlertid Hinrichsens Søn ikke har den lovbefalede Alder, og ingen sarlige Grunde foreligger, saa besluttede $H$. paa Pastor Knuths Anmodning at lade Drengen besøge Skolen endnu et Aar.

Fra Knuth gik Hinrichsen over i Kirken for at hente sin Salmebog, som havde ligget der i længere Tid uden at blive benyttet, da $H$. ikke havde besøgt Gudstjenesten siden de danske Præsters Fjernelse. I Kirken saa han nu, hvorledes alt blev forberedt til den følgende Dags Højtideligholdelse. En Aresport var rejst ved Indgangen til Kirken, Oprorsfanen og andre Ting saas uden- og indenfor Kirken, og alt havde et saare politisk Præg.

Da Hinrichsen gik ud af Kirken, modte han Hr. Godt, som han imidlertid ikke straks genkendte, men antog for Degnen. (H. er nemlig meget kortsynet, og $\mathrm{Hr}$. Coult talte Plattysk ligesom Degnen). Godt spurgte nu, hvorledes det var gaaet $H$. hos Pastor Knuth. H. fortalte nu, hvad Resultat han havde naaet hos K. Da Godt mærkede, at H. ikke genkendte ham, spurgte 
han: "Kender De mig ikke?" - H.: "Jo, nu kender jeg Dem, De er jo Generalsuperintendenten!« - G.: »Kender De mig da ikke fra Kirken?" - H. "Nej.» - G.: "Konmer De da ikke i Kirken?" - H.: "Jo, før kom jeg der flittigt, men hos Dem har jeg endnu ikke været der.« - G.: "Hvor kan det være?» - H.: "Skønt jeg ikke holder af at tale om Politikken paa dette Sted (Kirkegaar(ien), saa kan jeg dog ikke undlade at svare Dem paa Deres Spørgsmaal og vil derved komme til at berøre Politikken. Hvad er det for en Eresport og for Flag, man ser der (pegende paa Kirken)? og livad er det for et Ord, som bliver forkyndt derinde i dette Guds Hus? Er det ikke lutter Politik? Og tror De maaske, at jeg ikke ogsaa ved, at man paa hin Dag, hvor vi alle skal samles og stilles for den Almægtiges Domstol, ikke bliver spurgt: Har du været Tysk eller Dansk? Har du haft et slesvigholstensk Flag paa dit Hus eller ej? Og naar der drives Politik, hvor det rene, uforfalskede Guds Ord skulde forkyndes, saa falder Skylden for denne Kirkes Vedkommende paa Dem, da De ikke blot er Hovedpræst ved denne Kirke, men endogsaa overste Gejstlig for hele Hertugdømmet«.

G.: »De skulde dog komme selv og hore, om De ikke syntes godt om det Ord, der forkyndes her.« - H.: "Nej, det gør jeg nok ikke, thi jeg har lert: Frygt Gud og ar Kongen! og vilde altsaa ikke kunne opbygge mig ved det Ord, som forkyndes her, men tværtimod ægre mig; og det hedder: Wehe dem, durch welchen Ärgernis kömmet" [Ve den, ved hvem Forargelsen kommer]. - G.: Kom alligevel i Kirke, kære Mand. De fleste synes dog godt om det Ord, der forkyndes her.« - H.: "Jo, det tror jeg nok; thi den store Flok gaar som altid helst den brede Vej, og naar De som Hovedprast verl denne Kirke og øverste Gejstlig i Hertugdømmet kan forsvare at føre Folkene ad den brede Vej, saa kun til. Jeg holder mig til den lille Flok og gaar den snævre Vej." - G.: "Jeg lover Dem, at der jkke tiere skal falde politiske Ord i Præedikenen, kommer De saa? - J. H.: "Jeg lover Den intet«. - G. "Kom dog i Kirke, jeg vil heller ikke sige, at De skal komme i Morgen.« - H. "Farvel!« 
Dette har jeg af Hinrichsen selv, og desuden har Hinrichsen sagt mig, at han troede at bemarke, hvorledes Godt følte sig beskæmmet.

21. Januar 1865: Da man i denne Tid atter taler stærkt om en nær forestaaende Udskrivning af Hertugdømmets unge Mandskab til Krigstjenesten, strømmer ugentlig flere og flere unge Mænd til Herredsfogderne for at blive slettet ud af Lægdsrullen. Nu har jeg altid været af den Mening, at Fredsartiklerne tillod en Udskrivning af Lægdsrullen her og en Indskrivning et eller andet Sted i Kongeriget. Men det lader til, at Øvrigheden herovre er af en anden Mening. Da jeg imidlertid til flere og paa mange Steder har paastaaet, at en Udskrivning var lovlig, er jeg nu fra flere Sider bleven anmodet om at forskaffe mig en Autoritets Udtalelse om denne Sag.

Jeg tillader mig derfor at bede Dem om, godhedsfuldt at ville meddele mig noget desangaaende. Der skal hertil allerede være indkommet flere Hundrede Ansøgninger i ovennævnte Retning, og dertil kommer endnu den Omstændighed, at mange af de ved Freden hjempermitterede Soldater slet ikke har afleveret deres Permissions-Attest, fordi de tror derved at kunne undgaa at blive indkaldt af den nuværende Regering. Imidlertid er der nu indtraadt en Standsming i den nævnte Strømning, da Folk paa Grund af de tidligere Ansøgningers Ikke-Besvarelse kommer i Tvivl om Muligheden af en Udskrivning.

Forresten er man rigtig vaagen herovre; thi man modstaar og arbejder i Stilhed, den ene trøstende den anden. Af og til bringer de tyske Aviser meget gavnlige Efterretninger, især naar de taler om Ruslands Indblanding i vor Sag. Man taler om, at Hjemmetyskerne agter at rejse en Landstorm, der skal udjage Preusserne og indkalde Arvefjenden. En prægtig Idé!

Den loyale Befolkning er ogsaa meget virksom, hvilket De snart vil kunne erfare andre Vegne fra. Man har nemlig $i$ disse Dage sendt en A d resse til Kejser $\mathrm{Napoleon}$, hvori han bedes om at kommer os danske Slesvigere til Hjælp. Der er ind- 
kommen en Masse Underskrifter, og selv i Byen Slesvig og dens Omegn har man faaet et betydeligt Antal Underskrifter. Sagen holdtes slet ikke videre hemmeligt $i$ de Dage, da Adressen bares omkring, og dog har man slet ikke hørt noget om, at Politiet har faaet fat $i$ en eneste af de mange Adresser. En af mine Venner her i Byen fik i en Time samlet 120 Underskrifter. Havde man haft flere Adresser, havde man faaet langt flere Underskrifter, men uheldigvis fattedes det tilsidst paa Adresser.

Om min lille Fornøjelsesrejse i Angel og til Treja har jeg vel fortalt $\mathrm{i}$ min sidste Skrivelse, og tør jeg nu paastaa, at den ikke har været forgæves. Hvad kunde der ikke virkes, naar f. Eks. en formuende Patriot vilde give sig til at understøtte den under en tysk Pengemand staaende Danemand. Jeg mener dermed ikke, at Pengene skulde foræres de vedkommende, nej, dc vilde med Glæde forrente og med Tiden tilbagebetale dem. For Tiden kender jeg to værdige trængende, hvoraf den ene sandelig midt i sin Nød af alle Livets Kræfter virker for den gode Sag. Kunde saadanne Folk ikke betragtes som wbetrængte Slesvigere«, og som saadanne faa en lille Understøttelse, et Laan? Maaske tør jeg ogsaa her vente at faa et godhedsfuldt Svar fra Dem? I paakommende Tilfælde kan Provst Hansen give Oplysninger om de anførte Mænd. Gid de kunde hjælpes af en Dansker!

Har De læst "Schwarzbücher der dänischen Missregierung im Herzogthum Schleswig«? Disse Bøger er jo fulde af Løgn, og det maatte være en let Sag for dem, der er berørte i disse Bøger, at opdække dette Løgnevæv. Jeg har - skønt jeg ikke er næunt i disse Bøger - dog paataget mig at gendrive nogle enkelte Beretninger og agter at sende denne Gendrivelse til "Kölln. Zeitung«. Tør jeg ogsaa heri udbede mig Deres Mening?

I Søndags var jeg med et Par Venner kørende til Aabenraa. Vore Heste var prydede med røde og hvide Baand. Det kan nok være, at vi ved disse uskyldige Farver opklarede mange alvorlige Ansigter, især var man i Aabenraa glad til os. Vel indser jeg, at man i de fleste Kredse vil kalde dette Kaadhed, der ikke 
forer til noget, og jeg giver saadanne Udtalelser Ret; men paa den anden Side var det kun en uskyldig Fornøjelse, og Farverne er jo ikke forbudte. I Aabenraa er man forresten ved godt Mod, og Byens hæderlige Borgere holder fast sammen i denne Nødens Stund. Mange af disse Mænd samledes om os i en trosindet Borgers Hus, og mange trøstelige Ord veksledes. Ogsaa der var man dengang i Færd med at samle Underskrifter til den omtalte Adresise. Lorerne i Aabenraa har vist jkke den behageligste stilling for Øjeblikket, men det lader til, at de holder sammen.

Civilkommissæreme skal have været uenige indbyrdes, da Østerrigeren ikke vilde have Regeringssæet forlagt til Slesvig, og Folk, der i Almindelighed er velunderrettet, paastod endnu i Forgaars, at L'enigheden fremdeles var vedvarende. Imidlertid tror jeg ikke, at Østerrigeren vil gøre Alvor af sin Modstand, Preusseren vil nok atter sejre. Zedlitz har forleden udtalt til en iansk Flensborger, at han meget godt vidste, at Flensborgerne var dansksindede.

Her indskydes 2 interessante Breve, som er stilede til Provst Aleth Hansen, men er videresendte til Regenburg.

Flensborg, 9. Febr. 1865. .... Gamle Ewalds tilligemed de fleste «Grumtoft Sogn«s Længsel efter den gode gamle Tid bliver med hver Dag stærkere. Imidlertid bliver Haabet ogsaa større Dag for Dag. Paa en Adr. .... til Hs. Maj. Kejs. .... Nap. .... har jeg faaet over 50 Underskrifter i Gr.... - Med Trængslen voxer Modet, og Tanken om vor gode Ret opliver, da vi vide, at Retten endelig skal seire.

Klein-Rheide, 14. Apr. 1865: Med megen Glæde har jeg modtaget Deres ærede Skrivelse af 28. Febr., og skønt den var en hel Maaned gammel, har den dog vakt min og vore gode Grumtofters Glæde .... Ja, højærværdige Herr Provst, jeg tor forsikre Dem, at ethvert Ord af Dem og andre Venner derovre fra virker meget. Især er det mig og andre til stor Nytte, da det statter vore Udsagn og derved bliver en Sanktion af, hvad vi fortæller vore Trosfæller for at opretholde 
deres Mod. De kan tro, at der hører en hel Pose fuld af opmuntrende Ord til at kunne have noget til enhver. Jeg har næsten hver Dag Besøg af mine gode Venner fra Grumtofte, og selv fra andre mindre kendte Egne kommer Folk til mig; thi i denne Tid bliver man let familiær med sine Trosfæller. Jeg søger ogsaa at hjælpe de tro blevne, hvor jeg kan, og min lille Formue bliver mangen en Hjælp i Nøden.

Gaar Haabet i Opfyldelse - og det er jeg ligesom De vis paa - saa vil jeg jo med Glæde kunne se tilbage paa denne T'id. Den meste Glæde har jeg af Grumtofterne, thi de er altid flinke til at hjælpe, naar det gælder et Foretagende $i$ dansk Retning: .... Grumtofte er og bliver Kærnen; det danske Parti dominerer næsten. De fejrer Kongens Fødselsdag, kommer sammen og siger Tyskerne Sandheden .... Tusind Tak for de Oplysninger, De bragte mig fra R.[egenburg]; jeg har allerede takket ham selv. Fader lader ogsaa takke mangfoldigst ved mig; han er saa glad til al den Deltagelse, hans gamle Foresatte viser ham. Min Kone, Datter og jeg er i denne Tid hos vore Gamle her i Kl.-Rheide. Her længes man ogsaa efter Danskens Genkomst. ....

5. Marts 1865: Da jeg $\mathrm{i}$ den sidste Tid har været meget beskæftiget med Udbredelsen af - franske Ideer [Adressen til Napoleon], og da jeg gerne først vilde kunne fortælle om mine Bestræbelsers Frugter, har jeg indtil i Dag opsat at skrive til Dem. Hist og her er det lykkedes mine svage Kræfter at faa et - efter Forholdene - betydeligt Antal - [Underskrifter], saa jeg indtil i Dag kan regne det samlede Antal fra de forskellige Sogne til mellem 150 og 200. Andre Steder er det gaaet mindre godt. Saaledes skriver en til mig: "Det ligger ikke ved mig, naar jeg kun bringer en halv Snes -, men Folk siger, at det nok vil blive godt uden deres Medvirkning; den gode gamle Tid vender nok tilbage." En anden siger: "Her er man ikke enig med - - Ordlyd; thi man onsker det hele tilbage." En tredie siger: "De fleste er bange for Mikkel [Tyskerne], ellers 
havde jeg faaet flere - - Et Sted, hvor jeg ventede at faa en Masse, fik jeg kun grumme faa, da de saakaldte "kloge" ikke vilde. De fleste tog hellere Jerntyven end Pennen i Haanden, naar det bare nyttede. Det mangler ikke paa Patriotisme, thi først nu ser man Mængdens sande Sindelag. Det er ofte rørende at være Vidne til Folkets Kærlighed til alt, hvad der er dansk, og man overraskes tit af Menigmands aabenlyse Ytringer i denne Sag.

Medens jeg forleden stod $i$ en Boghandlerbutik, kom der en gammel Bondemand ind og spurgte om danske Billeder. Man viste ham forskellige, men han kasserede dem alle. "Hvad skal det da være for Billeder?" spurgte Boghandleren. "Det skulde være Billeder, hvorpaa der var et Slag mellem Tyske og Danske, og hvor de første fik Bank, eller i det mindste saadanne, hvorpaa der var tegnet noget, der var til Danskens Fordel; thi Drengen, som skal have Billederne, er meget syg, og dette vilde ene kunne glæde ham", svarede Manden.

I Forgaars blev to Bønder fra Bov arresterede, men de slap straks fri igen. I Dag er Købmand Schrøder fængslet, og jeg er bange for, at man vil tage flere. Maaske kan jeg ogsaa vente at komme $i$ 'Arrest. Jeg er for lidt siden bleven advaret, og da jeg dog gerne først vilde fortælle Dem lidt, skynder jeg mig med at faa noteret, hvad jeg for Øjeblikket ved af Nyheder. Det er for - [Adressens] Skyld, at de nævnte Folk er arresterede, og nu er der jo stor Sandsynlighed for, at man tager mig med, navnlig da S. er arresteret. Naa! ogsaa det kan en ærlig dansk Mand taale, og jeg vil ikke knurre mod Skæbnen, hvis den skulde tilføje mig en saadan Ubehagelighed. Haabet om Sollysets snarlige Genkomst opliver til Fremadskriden paa den betraadte Vej. -

Jeg kan ikke undlade at tilføje, at Borgerforeningen næsten er mere dansk nu end i Fredsaarene, i det mindste mærker man det' denne Tid bedre. Nylig var der Bal, og som jeg har hørt, har man paa dette Bal ikke lagt "Haanden imellem «, men udtalt sine Forhaabninger og Ønsker aabenlyst. Man har endda 
udbragt Kongens Skaal. Handelsforeningen har da ogsaa fornylig vundet en Sejr over Hjemmetyskerne, idet den gamle, dansksindede Bestyrelse blev genvalgt.

Vor nuværende Stadssekretær B ri n k m a n n ytrede forleden til en Borger her i Byen, at Dansken jo endnu let kunde komme igen. Disse Ord faldt i en let modtagelig Jordbund, og mange ligesindede har haft godt af denne Herres Udtalelser. Det er ellers slemt, at Folk ikke kan udskrives af Lægdsrullen uden at flytte til Kongeriget. Vel faar Preussen ikke ret mange unge Mennesker til Soldat, men det er dog ubehageligt for disse ikke allerede nu at være sikker for preussisk Tjeneste.

Den franske "gule Bog " har bragt nyt Liv i de trofaste, og Modpartiet er blevet betænkeligt, thi Frankrigs Holdning $\mathrm{i}: H e r-$ tugdommets Sag" synes alle af stor Vigtighed. Man ser her allerede alle Veje og Marker fyldte af fransk Militær. Selv den tyske Dr. Lorenzen skal efter Folkets Fortællinger have haft et lignende. Gud give, at det ikke bliver ved Synerne! -

Nu er da ogsaa Provst Peters entlediget fra sit Provsteembede, og Vol qu a r d $t \mathrm{~s}$ er traadt $\mathrm{i}$ hans Sted. Gud ved, hvad Hr. V. nu vil gøre sig berømt ved.

Har vi blot Vished for den gode Tids Genkomst, saa er det jo en Lyst at lide lidt.

13. Marts 1865:

Da jeg tror, at det vil være af Interesse at høre, hvad der $\mathbf{i}$ denne Tid passerer herovre, tillader jeg mig $i$ al Korthed at fortælle lidt om de mangfoldige Arrestationer, som i denne Tid har fundet Sted.

Købmand Schrøder i Norden har nu haft Arrest i 8 Tage, og endnu er der ingen Udsigt til, at han saa snart skal hlive befriet. Han vil ikke tilstaa, til hvem han har sendt de til Kejser Napoleon rettede Adresser. J. P a r ts ch har ogsaa været i Forhør, og i Morges skal han og flere andre paany i Forhør. Ogsaa flere Bønder har været i Forhør, navnlig fra Bov og Harrislev. I Torsdags var hele Duvenstedts (ved Rendsborg) 
Bønder i Forhør, og D. M. He n s e n fra Brekendorf har allerede 2 Gange haft samme Skæbne. Alt paa Grund af Adressen til Kejser Napoleon. Forleden var ogsaa en tro Slesviger hos mig, han fortalte mig meget, som, jeg en anden Gang skal tillade mig at skrive. Han bragte mig en - [Adresse] fra 70 ansete Mænd. Der kommer endnu flere -, sagde han, naar jeg vilde hente dem. -

Her i Flensborg har man faaet Adresserne af den ny lig a f d ø d e Kasserer ved Gasværket, A. B. C. D i t t m e r. Vor vise Øvrighed mener, at Adressens Ophavsmænd sidder i Kongeriget, og det er det, de vil vide. Den gode Politimester faar spørge den hensovede, siger min Ven. Til $\mathrm{Hensen}$ fra Brekendorf sagde Herredsfogden i Fortrolighed, efter at man ikke kunde bevise $H$. noget, at han maatte vide, at en saadan Adresse kunde skade Landets (Schleswig-Holsteins) Sag! Det lader forresten til, at man ikke vil gøre saa ret meget af denne Sag, da der er Fare for, at Sagen vil komme til at blive - [Adressen] for storartet. Her er en formelig Enthusiasmus for de arresterede. -

Af Forsigtighed skriver jeg i denne Form.

25. Marts 1865:

Feberen er overstaaet, Blodet er atter roligt, og - Arrestationerne er ophørte. Det var ellers en interessant Tid! S c h r øder og Ty ch sen er ikke længere i Arrest, dog er de kun losladte imod Kaution. S. har ogsaa faaet Tilladelse til at gøre en Forretningsrejse til Jylland. Iøvrigt lader det til at være Civilregeringen uvelkomment med de mange Arrestationer, og man paastaar, at vor vise Politimester har faaet en alvorlig Irettesættelse for $\sin$ store Tjenestiver. Det kedeligste af alt var nok, at ingen kunde sige Øvrigheden, at Adressen var kommen og atter gik til København. At Slesvigerne selv kunde finde paa saadanne Demonstrationer, er vist meget ubehageligt, thi man vil jo dog saa gerne gøre os til Tyskere. V'i har imidlertid faaet' Øjnene oplukket og taget Lære af Tyskerne, saa det 
aldrig vil faa Ende med vore Veraab og Smertensskrig, førend man atter giver os tilbage til Moderlandet.

Ogsaa i Sydslesvig har man hørt op med at forske efter Adressen. Regeringens salvelsesfulde Opfordring til de loyale Beboere af Hertugdømmet har Aviserne jo alt berettet om, og kan jeg kun fortælle, hvad Indtryk den gjorde her. Alle var straks enige $i$, at man ikke turde straffe os, og at man bare vilde kyse os med disse haarde Ord. (Adressen siger nemlig, at man $h$ e r e f t e r vil straffe saadanne Demonstrationer efter Lovens fulde Strenghed).

Mest af alt har den Efterretning, at den franske Regering har forespurgt sig i Berlin og Wien angaaende disse Adresser, oplivet Haabet og fornyet Modet, og man er nu aldeles sikker paa, at Frankrig vil hidfore en heldig Ordning af vore Anliggender. I Angel har man allerede set Franskmandene, og min Købmand fortalte sidst, at der allerede havde været en Mand her fra Byen hos ham for at købe Tøj til Sengeklæder og Dannebrogflag, alt i Forventning om Franskmændenes Komme. Andre er visse paa, at Russerne kommer, saasnart Søen er aaben. Man synger allerede den fra 1849 kendte Vise: "Wir brauchen keine Preussen mehru [Vi behøver ingen Preussere mere].

Paa Preusserkongens Frdselsdag var hele Byen illumineret - efter Anmodning fra Magistraten. Rigtignok brændte enkelte Enskillingslys, og eet Sted har man i de oplyste Vinduer last: "Nicht aus Liebe, nur aus Pflicht brenne ich mein Dreilings-Licht«.

Nu skal jeg dog fortælle, hvorledes det i Begındelsen gik med Adresserne i Sydslesvig. I Slutningen af Januar Maaned sendte jeg en Adresse til min Ven H. i T., og da jeg ikke straks kunde faa flere Eksemplarer tilvejebragt, maatte jeg vente noget med at tilsende andre gode Venner en lignende. $H$. fra $\mathrm{T}$. gik imidlertid til sine Venner i Omegnen og viste dem Adressen. Disse blev indtaget i dette Forehavende, og for nu ogsaa at kunne virke i samme Retning, skrev man den af. Da jeg nu 
noget efter sendte et Par andre af Sted, fik jeg siden til Svar: "Vi saa Adressen hos $\mathrm{H}$. og skrev den af i flere Eksemplarer; alt er i Orden, og vi er snart færdige med at bære den omkring«. Er det ikke et herligt Bevis paa Sydslesvigernes Troskab? Efter min ringe Mening er det derfor utilgiveligt kun at arbejde for Nordslesvigs Tilbagegivelse.

Man har herovre paa flere Steder svært Lyst til at sende en Adresse til Kejser Alexander, da det forekommer os, at Hjælpen muligvis kunde komme ligesaa hurtig fra Øst som fra Vest.

Hjertelig Tak for de mig gennem Hr. Provst Hansen tilsendte Oplysninger. De to trængende, jeg engang talte for, er ved mig kommen ud af Trangen og er nu atter ovenpaa. Turde jeg imidlertid haabe en anden Gang at kunne bevirke, at andre trængende ad den Vej kunde blive hjulpne, saa skulde det være mig en stor Glæde. Jeg selv har atter lidt et betydeligt Tab i mine Indtægter og er nærved at føle mig nødt til at ty til andres Hjælp, dog har jeg endnu mit Udkomme.

Naar Udrulleringen ikke kan gaa paa den Maade, som vi herovre troede, saa maa vore kongerigske Brødre i paakommende Tilfælde vide at kunne tage imod Flygtninger en masse.

15. Maj 1865: Undertegnede tillader mig herved at tilsende Dem indlagte Protokols-Ekstrakt.

Slagter G. P a r t s ch er rejst til Berlin for der at tale med Bismarck og den franske Gesandt. I Aftes udbragtes meget patriotiske Skaaler i Borgerforeningen. Den preussiske Militærmusik spillede, men da den ikke vilde istemme i Skaalen for Kong Christian IX, bad Direktionen den om - -at gaa. Angelboerne begynder nu atter med at sende deres Børn til fremmede Skoler, thi de nye Skolemestre er mindre dygtige.

5. Juni 1865: Overlærer M o n rad har været hos forhenv. Borgmester J e n s e n og andre og er for Tiden virksom i Nordslesvig. Underagenter, hvortil man ogsaa vilde have mig, faar 
14 Thl. pr. Dag og Løfte om snarlig og god Ansættelse. Dette kan naturligvis ikke bevæge mig til at gaa ind paa et saadant Andragende, men alene Tanken om at kunne komme Augustenborgerne til Livs har noget tillokkende for mig. Dog, intet skal bevæge mig til at gøre imod Deres gode Raad, og stiller jeg mig aldeles til Deres Raadighed. Maaske tager De heller ikke imod et saadant Tilbud fra min Side, men, højvelbaarne Herr Etatsraad, jeg trænger saa snart til at blive et Redskab til den gode Sags Fremme og vil saa gerne gøre lidt for denne Sag. De sagde til mig, at jeg i paakommende 'Tilfælde kun skulde henvende mig til Dem, og nu mente jeg, at jeg ogsaa i denne Sag turde komme til Dem. Jeg bad om en lille Rejseunderstøttelse, hvis det var Deres Agt først at tale personligt med mig, men bagefter er jeg kommen i Tanker om, at jeg allerede for nogen Tid siden har modtaget 50 Rdlr. Dem har jeg imidlertid brugt og kan for Øjeblikket ikke undvære en Skilling, thi mine Indtægter er betydelig formindskede, da Finansministeriet kun har bevilget mig 168 Rdlr. aarligt i 3 Aar. Af disse 168 Rdlr. skal jeg for i Aar tilbagebetale omtrent 30 Rdlr., som jeg har faart for mange $i$ de forløbne 5 Maaneder. Min Privatfortjeneste or ogsaa bleven mindre, saa at jeg kun med Nød og næppe kan ernære min Familie nogenlunde anstændig.

Imidlertid tillader jeg mig endnu engang at forsikre, at jeg med Liv og Sjæl har hengivet mig til den gode Sag, og det vilde være min største Sorg at blive nødt til at opgive min Virksomhed i denne Retning.

Dette, højvelbaarne Herr Etatsraad, maa tjene til Undskyldning for min Ligefremhed, og haaber $\mathrm{jeg}$, at De ikke vender Deres Godhed fra mig; jeg skal stedste bestræbe mig for at være den værdig.

30. Juni 1865: Maaske lykkes det mig med det første at faa nogle Petitioner om Genindførelse af dansk Skole- og Kirkesprog i det nordlige Angel tilvejebragt. Jeg mener, naar vi 
stiler disse Petitioner til Civilregeringen, kan man ikke derfor fortrædige nogen.

2. Juli 1865: Den preussiske Agitation bliver større Dag for Dag. For at vinde de dansksindede bliver man ved med at slaa ned paa Augustenborgerne. Man søger ved personlige Samtaler med de dansksindede og ved at tilsende disse Blade og Skrifter, der i preussisk Aand med et dansk Anstrøg river ned paa Augustenborgerne, at vinde enhver Dansk.

Den bekendte Slagter $\mathrm{P}$ a $\mathrm{r} \mathrm{t} \mathrm{s} \mathrm{c}$ h hersteds havde forleden Besøg af Redaktøren for det preussisksindede Blad "Der Beobachter an der Elbe". Manclen har forstaaet at indvirke paa Partsch, ikke at han er bleven tysk, men han er dog bleven lidt smittet af Redaktørens preussiske Tænkemaade. Han har modtaget en Del Prøvenumre af nævnte Blad, og da disse Numre river grueligt ned paa Augustenborgerne, saa er mange indtagne i Bladet. Bladene tilsendes ham pr. preussisk Feltpost, og dette bliver ved, indtil Folk selv forlanger Bladet paa Posthuset. Ogsaa jeg er bleven anmodet om at gøre Folk bekendte med Bladet og lade dem læse nogle Artikler af dets sidste Numre. Kammerjunker Bertouch har gennem Kontorist Petersen i Slesvig tilsendt mig Bladet med den Bemærkning, at jeg godhedsfuldt sorgede for de deri indeholdte Artiklers offentlige Udbredelse. Jeg har imidlertid kun ladet nogle tro Venner læse Bladet, da Partsch er meget ivrig for Bladets Udbredelse.

Det sidste Nummer indeholder "Adressen fra Sundved til de gamle Augustenborgere». Ogsaa denne Adresse er fremkommen ved preussisk Agitation, i det mindste ved Preusserne Besked om den.

Jeg var forleden i Angel. Der var gjort et lille Gæstehud, og mange gode Venner samledes med mig. Vi talte om, at jeg vistnok var den eneste danske Skolelærer, der i Aar som for kunde besøge mine Venner i mit Sogn, og mal, forsikrede mig, at min Nærværelse var dem til stor Glæde og Opmuntring. Dette glædede mig at høre, men det bedrøvede mig tillige; thi 
jeg ved, at man vil holde det for et daarligt Varsel - ikke jeg, thi jeg kender min Lidenhed -, naar jeg maaske om kort Tid ser mig nodt til at søge herfra. Ja, højvelbaarne Herr Etatsraad, jeg føler mig saa uendelig nedtrykt $i$ deme Tid, thi der er jo al mulig Udsigt for mig til at forlade det kære, dyrebare Slesvig.

10. Sept. 1865: Endelig har jeg da faaet Ro til atter at tage fat paa Pennen for at nedskrive et og andet, der maaske turde interessere.

Da jeg i Begyndelsen af August var i Angel for at virke for en Henvendelse fra Befolkningens Side til Civilkommissærerne med Bøn om Genindførelsen af dansk Skole- og Kirkesprog, kom jeg ogsaa til Langballe. Medens jeg her en Middagsstund sad hos min tidligere Nabo Skomager $\mathrm{Høck}$, kom en af mine forhenværende Elever ind $i$ et Erinde for sin Fader. Da han saa mig, kom han meget venligt hen og hilste paa mig. I vor danske Samtales Lob bad jeg ham om at hilse de andre Skoleborn fra mig. Efter at han havde været borte et Kvarters Tid, kom andre to Elever blot for at hilse paa mig. Efter dem kom atter andre to, og saaledes gik det i nogen Tiıl, men saa kom min Værts Kone ind og bad mig om at se ud paa Vejen. Der saa jeg den hele Skole, store og smaa, tysk- og dansksindede Forældres Børn staaende paa r'ejen. Jeg gik nu ud til dem, og det var mig en overordentlig Glade at se ind i de kære Smaas glıdestraalende Øjne og høre deres muntre, glade, danske Svar. Imidlertid blev Klokken temmelig mange, ja, der gik vel henimod en halv Time af Skoletiden, saa jeg maatte bede dem om at gaa tilbage til Skolen. Gerne var de smaa blevne endnu en lille Stund hos mig, men paa min Anmodning gik de dog straks tilbage til skolen. Gud give, at jeg snart igen maatte komme til at vare saadanne smaa's Vejleder i Herren!

Jeg oplevede naturligvis meget glædeligt paa denne lille Rejse, men - „Per Degn« [Degn H. M. Tofte] har nok fortalt det meste. Jeg er af den Mening, at det nok vil gaa med Peti- 
tionen, og jeg vil med det første gore mit for at faa Sagen til at blive virkeliggjort.

Den danske Læseforening fik jeg da samlet den 27. August, og der blev besluttet, at vi den (6. Oktober atter skulde holde Møde. Der er fra flere Sider indkommen Anmodning fra angelske Bøncler om Optagelse i Læseforeningen, men paa den anden Side virker Formanden, Bottcher i Hatlund, ikke til det bedste med sin Egenraadighed og Paastaaelighed, ja, man har endog sagt mig, at meget agtede Medlemmer ikke vil møde, naar han vedbliver at spille den raadende. Han var ogsaa skyld $i$, at flere Angelboere uileblev fra Lystturen til Kobenhavn.

Det var ellers en herlig Tur, og den vil have gode Følger! Hvor Bønclerne dog var glade, da de kom hjem! Rigtignok har ogsaa demue Tur kostet mig en Del Arbejie, thi Angelboen er bange, naar det gaar til Pengepungen. Derimod var man næsten mere villig i slesvig og Omegn, og havde jeg straks sendt dem en Liste, saa havdle langt flere Sydslesvigere taget Del i Turen. Man var her af den Mening, at ingen tysktalende skulde med, derfor sendte jeg dem forst en Liste, efter at de gennem Petersen i Slesvig havde anmodet mig derom. Bare disse gode Folk dog ogsaa maatte blive dansk igen! Jeg kan imidlerticl ikke undlade at bemærke, at næsten alle Foretagender i dansk Retning bliver ledet daarligt. Saaledes fik jeg ved andre tro Folks Assistance 600 Underskrifter paa FlensborgTelegrammet til Klampenborgfesten, alene her i St. Johannes Sogn, og 9.10 kom der kun i det hele. Der burde efter min Regning vare kommet 3 - 4000 Underskrifter. Sagen er den, man vil ikke lade Sagen konmme i os smaas Hrnder.

Nu har jeg i denne Tid travit med at faa Folk i Angel og Sydslesvig til at sanle smaa Pengebidrag til Centralkomitren i Kobenhavn. Om nogle Uger venter jeg Resultatet af disse Bestræbelser. Her har man enclnu ikke gjort noget i den Retning. De vil kumne indse, at jeg ikke har ligget paa den dovne Side, endskønt jeg ikke har meddelt noget i en meget lang 
Tid. Jeg mener, at jeg først maa gøre min Pligt hernede i det kære Slesvig, mine Beretninger er vist af mindre Værdi, og saa er der jo ogsaa Folk nok til det sidste. Vel ved jeg, at mine Gerninger kun er smaa, og ogsaa føler jeg tit, hivad det vil sige at huse "Smalhans «; thi vel siger Hr. M[onrad] og "Peer Degn" hersteds undertiden til mig, at jeg kun skal komme til dem, naar jeg bruger - [Penge], men jeg kan ikke altid blive af med mine Bønner. Dog maa jeg med Tak tilstaa, at jeg en Gang har modtaget 33 Rdlr. Imidlertid arbejder jeg for en indre Faktor, og det er den, der tilskynder mig til mine smaa Gerninger.

Ja, højtærede og højtagtede Herr Etatsraad, med en inderlig Lyst og Stolthed vil jeg arbejde for mine stakkels Brodre, saalænge jeg kun nogenlunde kan forsvare det for min Familie. Her kan jeg dog ikke faa en fast Virkekreds, thi jeg ved, at jeg paa en vis Liste er betegnet som en "unverbesserlicher Däne« [uforbederlig Dansker], der ikke kan vente atter at blive ansat. Det var mig en Glæde at høre dette; thi jeg har heller slet ikke tænkt paa at tage Tjeneste under Røverne.

28. Sept. 1865: .... Folkets Sind er foranderligt! I Angel har de tyske Bonder besluttet at sætte en Adresse i Gang, hvori de erklærer, at de onsker at komme tilbage til Danmark. Endnu er der dog kun valyt enkelte Mænd, der skal stille sig i Spidsen for denne Adresse. Blandt disse Mænd er min Ven (?) Hansen i Langballe, han, der ved Preussernes Komme var den ivrigste til at fordrive de danske Embedsmænd. Jeg har tilfældigt faset fat $i$ denne Nyhed og ment at burde bevare den, da en for tidlig Offentliggorelse her kunde skade meget. Imidlertid tor jeg staa inde for, at Tyskerne tænker paa ell saadan Adresse. - Turen til København har været velsignelsesrig for den gode Sag, og den lille Pjece "Slesvigernes Besøg i København læser man i Angel med Lyst. Ogsaa har Mørk-Hansens Foredrag over "Den danske Bonde Laurids Skau" fundet en mageløs Indgang hos Angelboen. Her tror Menigmand, at Preussens Befæstningsarbejder ved Dybbøl tyder paa en nær 
forestaaende Krig, og man har allerede "set" Fransknı Spaniere i Angel.

Forhenværende Borgmester J e n s e n hersteds havile i Gaar Besøg af Manteuffel og kom ved demue Lejlighed til at fortælle Generalen, at vor gale Provst Volquards forleden ved en Præsteindsættelse kunde forglemme sig saa vidt at udbringe en Skaal for "den Angestammten" [Hertugen af Augustenborg]. Muligvis kunde disse Ord bidrage til at hjælpe os af med en af de største Slyngler. Manteuffels haarde - af mange kaldt latterlige - Ord har imidlertid ikke forskrækket os; alle Vegne bliver der gjort $\mathrm{Nar}$ ad den "Syvfodlanges" Tale. $\left.{ }^{12}\right)$

"Angler Zeitung« er i denne Tid ubetalelig, og den virker mere for den gode Sag end alle andre "Smaaagitatorer", den faar derfor ogsaa altid flere og flere Abonnenter.... Bladet har gentagne Gange haft fat paa de nye Skolemestre i Angel og forsøgt at gøre dem latterlig. Det er ogsaa et brillant Middel til at faa en Mand til at synke i Angelboens Øjne, thi for Latterlighed er Angelboen allermest bange. Jeg har enduu daglig Besøg af mine gode Angelboere; havde jeg mere Tid, vilde jeg kunne fortælle mange smaa kostelige Historier fra Angel, men - Tiden tillader mig ikke altid at beskæftige mig med det interessante. Een Ting erfarer jeg daglig: Angelboen vakler ikke i sit Haab og sin Tro!

20. Dec. 1865: Hansen - Gru in by har været i Aabenraa, talt med de nordslesvigske Stænderdeputerede og villet bevæge dem til at arbejde for en Personalunion med Danmark. Dette har man ikke villet indlade sig paa, og saa er $\mathbf{H}$. G. gaaet ind paa at arbejde hen til, at Nordslesvig bliver inkorporeret og Sydslesvig kommer i Personalunion med Danmark. 3. Juledag vil der her i Flensborg blive afholdt et Møde af. alle Stænderdeputerede; for at vildlede Folk, siger man her, at clette Møde skal finde Sted paa Torsdag den 21. ds.

Da De har vist saa megen Interesse for mig, tillader jeg 
mig herved at meddele, at jeg i min nuværende Stilling med Tiden haaber at faa et nogenlunde ordentligt Udkomme, endnu er det kun ringe. Ogsaa tillader jeg mig gentagende at takke for de 50 Rdlr., som jeg af Hr. M[onrad] modtog i Oktober; disse Penge kom just $i$ et Øjeblik, hvor jeg trængte særdeles liaardt til dem. Dog, dette har jeg vel allerede tidligere flere Gange talt om, saa jeg maa frygte, at De bliver ked af det, men Taknemmeligheds-Folelsen faar mig altid tiibage paa dette 'Ihema. Gud lømne Deres Hojvelbaarenhed!

For at være sikker paa, at De altid faar mine Breve straks, lader jeg dem nu gaa til Hr. Pastor F r e u chen.

Endnu eet niaa jeg tillade mig at gøre opmærksom paa: Det gor vore Folk heruede saa godt, naar de bliver rost i Bladene. Saaledes har det gjort et mageløst godt Indtryk paa dem i Sylvested, Treia og Munkbrarup, at de blev rost for de faa Penge, man derfra gennem mig indsendte til Centralkomiteen. Naar der staar et eller andet om Folk, jeg staar i Forbindelse med, i Aviserne, tager jeg disse Aviser og sender dem til vedkommende, og det har tit varet mig til stor Fordel sidenefter. Saaledes med Adressen til Napoleon, med Kobenhavnerturen og med Samlingen til Centralkomiteen, hvor Angler og Sydslesviger hver Gang navnes som brave Folk. Naar de saa har læst det, siger de tit til mig: "Ja, kære Johannsen, De har Ret; vi maa gøre mere af den Slags!“ Og - jeg tør saa komme igen. Kan De ikke give mig et Vink orn, til hvem jeg skal skrive, naar der sker noget med mine Folk, for at det kan komme ud, naar det ikke skader? De tilgiver vist gerne de gode Folks Egoisme.

Gud bevare gamle Danmark!

21. Febr. 1866: Følgende Telegram i "Nordd. Zeit.«: "Kopenlagen 20. Febr. Reichsrathsvolksthing: Der Finanzminister legt einen (iesetzentwurf, betreffend die fünfjährige Pensionscrhöhung der in Folge des Wiener Friedens entledigten Beamten vor" har bevæget mine her boende Kolleger til at anmode 
mig om i deres og eget Navn underdanigst at forespørge hos Deres Højvelbaarenhed - hvem vi endnu altid anser som den Autoritet, til hvem vi i slige Tilfælde først maa henvende os - om ogsaa vi med Bestalling forsynede afsatte Skolelærere hører med til de af Finansministeren nævnte Embedsmænd og -- hvis dette ikke er Tilfældet - hvad vi da skal gøre for ogsaa at komme i Betragtning ved den eventuelle PensionsForhøjelse.

13. Juli 1866: Herr Kollaborator M o n ra d har sagt mig, at han havde meddelt Dem, hvornaar og hvorfor jeg har set mig nødsaget til at forlade Boghandler Sundby, og tillader jeg mig derfor straks at komme med folgende Referat af min seneste Virksomhed.

Efter at forhenværende Lærer ved den danske Borgerskole, P. Vognsen, havde faaet Afslag paa sin Ansggning om Tilladelse til at oprette en dansk Privatskole her i Byen, indgav jeg under 27. f. M. en lignende Ansøgning. I Afslaget til Vognsen hed det, at han allerede, fordi han ikke kunde Folkesproget [Tysk], ikke kunde faa den forlangte Tilladelse. Dette kunde man jo ikke sige om mig. Jeg anførte i min Ansøgning, at mit Modersmaal var Tysk, og at jeg var født i det sydlige Angel. En tysk Oversættelse af min Dimissions-Attest og en dito af en Attest for min Virksomhed ved Sollerup Skole vedlagde jeg min Ansøgning.

Min Afsættelse og Virksomhed som Lærer ved Langballe Skole berørte jeg paa følgende Maade: "Am 4. Märts wurde ich von dem damaligen Kirchenvisitatorium der Probstei Flensburg meines Amtes als Lehrer in Langballig entlassen. Da der Herr Pastor Peters, Mitglied des hohen Schulcollegiums für St. Marien, kurz vor meiner Entlassung als Probst meine Schule inspicirte und seine völlige Zufriedenheit mit meiner Fertigkeit in der deutschen Sprache und meiner Wirksamkeit als Lehrer mehrfach aussprach, so erlaube ich mir Solches als genügendes Zeugniss anzufülıren«. 
Med denne Ansogning modte jeg hos Borgmester B ongSchmidt, og kom det mellem os til folgende Samtale: ${ }^{13}$ ) Jeg: Hr. Bürgermeister! Ich bin der Privatlehrer etc. - Borgmesteren: Sind Sie Seminarist? - Jeg: Ja. - B.: Wo sind Sie geboren? - J.- In Angeln. - B.: An welchem Institut arbeiten Sie? - J.: Ich arbeite an keinem Institut. - B.: Da Sie persönlich zu mir kommen, so sollen Sie auch meinen persönlichen Rat hören: Nehmen Sie Ihr Gesuch zurück; denn durch diesen Schritt schneiden Sie Sich alle Wege zur Weiterbeförderung ab. Drang zu einer dänischen Privatschule in dieser deutchen Stadt ist hier durchaus nicht, es sind Mittel zur Erlernung der dänischen Sprache in Ueberfluss, und Sie werden und müssen wissen, dass es nur politische Demonstration ist, wenn Leute dänischen Unterricht begehren. - J. Erlauben Sie, Herr Bürgermeister! von meiner Seite ist es nur eine Existenzfrage und keine politische Demonstration. - B. (hæftig): Wenn Sie es nicht als politische Demonstration betrachten und dennoch als geborner deutscher Mann Ihre Hand zu einnem solchen Werk bieten, und Sich als Mittel von der demonstrirenden Partei gebrauchen lassen, daun haben Sie meine Achtung verloren und werden allen Respekt verlieren. - J.: Herr Bürgermeister, Ich liess mich nie als totes Mittel brauchen und wüsste auch nicht, meine Achtung irgendwo eingebüsst zu haben. - B.: Ja, wenn Sie der genannten Partei angehörell, dann ist es eine andere Sache. Eein jeder ficht für seine Meinung. W'as ich gesagt, war ganz und gar privatim. Ihr Gesuch wird den geschäftlichen Weg gehen, und bin ich durchaus nicht genigt, dagegen zu wirken; denn solchen Demonstrationen soll man nicht ganz widerstehen. Aber (idet han vil give mig Ansøgningen tilbage) junger Mann! bedenken Sie Ihr eigenes Wohl und nelimen Sie Ihr Gesuch noch zurück, sonst ist ein jeder Weg zu Ihrer Weiterbeförderung für beständig abgeschnitten. - J.: Ich glaube Ihren Rat zu verstehen, muss aber bemerken, dass es mir von wenig Nutzen scheint, dem Rat des Bürgermeisters zu folgen, denn schon in Langballig meine ich erfahren zu haben, dass man 
mich nicht will; das Befördertwerden ist mir wohl schon verpönt von daher. -- B. Nein! das war damals, aber dies wird Ihr Unheil werden; denn wenn Sie auch heute eine dänische Privatschule mit Kindern gefüllt erhielten, über ein Jahr würde sie leer sein, und hier in einer deutschen Stadt wird über ein Jahr keine solche Schule mehr existiren. Nochmals! nehmen Sie Ihr Gesuch zurück und lassen Sie Sich überhaupt von der geannten Partei nicht gebrauchen, wenn Sie derselben nicht angehören. - J.: Herr Bürgermeister! wi gesagt, ich lasse mich nicht brauchen, ich gehöre selbst der Partei an und finde meinen Antragt berechtigt. - B.: Ja, so! Dann wird Ihr Gesuch den geschäftlichen Gang gehen, und ist es nicht unmöglich, dass Sie Erlaubnis bekommen. Adjø!

Allerede den 29. var Skolekollegiet sammen for at behandle min Sag. Peters maatte tilstaa Sandheden af mine Ord om hans Udtalelser og roste mig endydermere. Nu var man i Knibe; thi mod min Personlighed kunde ikke anføres noget, og dog vilde man gerne være fri for at give mig Koncession. Bong-Schmidt og Peters blev enige om, at jeg ikke kunde oprette et saadant Institut og holde det uden Understøttelse, og den kom naturligvis fra København. Dette kunde man imidtid ikke bevise, og da de ørige Medlemmer ikke var mod Bevilgelsen, saa blev man enig om først at indhente Regeringens Raad og Mening og sendte det hele til Zedlitz. Saavidt kender jeg Sagens Gang nøjagtig; noget videre ved jeg ikke endnu. Jeg skal imidlertid forfølge Sagen med Energi, om jeg ogsaa personlig skal tale min Sag hos Zedlitz og Scheel-Plessen.

Jeg har i den sidste Tid korresponderet' ivrigt med mine mange Bekendte omkring i Slesvig. De modtagne Breve har jeg leveret til Mon rad, der atter har givet dem til de la P ort, og vil denne sidste bruge dem hos den franske Konsul i Kiel. Dog, alt dette kender De vel bedre end jeg. Dernæst er jeg traadt i Forbindelse med Politidirektør $\mathrm{Herz}$ og har efter hans Opfordring i Forening med Pes ch ke i Slesvig organiseret et Opdagelses- og Efterretningskorps for Slesvig. 
Jeg er altsaa ikke ledig, skønt jeg ikke har noget, hvorved jeg kan tjene mit Brød til mig og mine. Er min Virksomhed af Værdi, saa vilde jeg bede Dem tænke paa mig, der gerne vil ofre om ogsaa mit Liv for Fædrelandet, men nødig vil fratage min Familie, hvad den endnu har tilbage. Meget er gaaet, og mere vil gaa, naar jeg ikke kan faa Hjælp. Jeg kunde jo gaa til Kongeriget og muligvis faa Ansættelse, saa jeg kunde hjælpe mig selv, men vilde det ikke være urigtigt af mig, da jeg dog ved min Nærværelse opretholder Modet og virker altid noget $i$ en ikke lille Kreds? Imidlertid haaber jeg med mine slesvigske Brødre, at Forløsningstimen snart kommer, og i dette Haab vil jeg slutte min Skrivelse til Deres Højvelbaarenhed.

Arbødigst og taknemmeligst

Gustav Johannsen.

27. Juli 1866: Med Deres nøje Kendskab til Flensborgs trofaste Befolkning vil De for længe siden være kommen til det Fesultat, at Magistratens Lykønskningsadresse til Preusserkongen, ${ }^{14}$ ) betragtet som en Cutalelse af Byens sande Stemning, er en stor Løgn. Flenshorgerne blev ogsaa som rasende, da Aviserne bragte nævnte Adresse for Dagens Lys. Der blev lagt forskellige Planer til at træde op imod den, men - Tugthusforordningen tilintetgjorde alle Planer.

Efter forskellige. Samtaler med Hr. M o n ra d blev jeg enig med mig selv om at forelægge hoslagte Erklæring ${ }^{15}$ ) for de paa samme undertegnede Mænd, der uden Undtagelse er Folk, der baade kender Befolkningen nøje og selv har betydelig Indflydelse paa deres Medborgere. Gerne havde disse Folk offentlig udtalt sig imod Magistraten, men - ogsaa her blev Tugthusforordningen til en uoverstigelig Hindring. Kan nu denne Frklæring af Dem benyttes, uden at dog de underskrevne nævnes eller kommer i Ulejlighed, saa var Hensigten naaet, og vilde vedkommende føle sig Deres Højvelbaarenhed meget forbunden. Bare det kom til en Afstemning! siger Flensborgeren. 
Haabet er endnu levende og Modet det gamle. Nærmer Afgørelsen sig først, saa man kan øjne den, da vil ogsaa Flensborgeren dristig træde op, selv naar han for en kortere Tid skulde lide Straf af sine nuværende Herrer. Længselen efter Genforening med Danmark vokser fra Dag til Dag og Hadet til Preussen ligesaa.

Fra den følgende spændende Forberedelsestid til Afstemningen 12. Marts 1867 findes desværre ingen Breve. Men allerede 6. Aug. 1866 skriver tidl. Degn $\mathrm{T}$ of t e fra Flensborg til sine gamle Præster, Graae og Munck: "Der gaar det Rygte, at Johannsen er arresteret for politische Umtriebe [politisk Virksomhed] i Angel. Gendarmerne sporger ud efter og om ham, saa meget er vist. Har faaet ham advaret. - Luften er svanger med uhyggelige Rygter. Forsigtighed udkræves«. Og den 3. Aug. samme Aar skriver Overlærer Monrad til Regenburg: "Johannsen, jeg og flere mener efter det forste Indtryk, at hemmelig Afstemning vilde være at foretrække, Partsch mente bestemt det modsatter.

I 1866 havde Gustav Johannsen paa Opfordring overtaget Sundbys danske Boghandel. "Han gjorde det“ - skriver Monrad 22. Nov. 1871 til Grosserer D. B. Adler - "mest for den danske Sags Skyld i Almindelighed, som en stærk Trang drev ham til at tjene paa hvad Maade han bedst kunde; men han fik ogsaa snart Forretningen kær. Han var i Besiddelse af en Formue paa vel omtrent en 7000 Rdlr., hvilket var fuldkommen tilstrækkeligt for ham til at etablere sig. Men Handelen var jo endnu noget aldeles nyt for ham; han var jo opdraget som Lærer og havde allerede nogle Aar virket som saadan - og den Tid, han havde til at lære Boghandlerforretningen, havde været meget kort. Intet Under da, at Boghandelen ikke gav ham et tilsvarende Udbytte, og at han i Lobet af de siden hengaaede Aar har sat største Delen af sin Formue til, et Resultat, der er saa meget lettere at forstaa, som der uafladelig fra alle sider 
har været stillet de videstgaaende Fordringer til ham om at opfylde en uendelig Mængde Hverv, hvis dygtige Udforelse var af den yderste Vigtighed for den danske Sag i Slesvig i Almindelighed."

Næste Brev er dateret 18. Maj 1869:

Der tænkes i denne Tid paa at sætte en Petition til Preusserkongen i Scene, og har man efter Raadslagning overdraget mig at indhente Deres Mening desangaaende.

Petitionen skulde udtale Nordslesvigernes dybe Sorg over den øjeblikkelige Tilstand, fremhæve vort store Tab ved Adskillelsen fra Moderlandet og udtale en Bøn om snarlig Udforelse af Pragerfredens Art. V. Den nordslesvigske Presse sḳulde i Forvejen fremhæve det aandelige og materielle Tryk, hvorunder vi lider, og saa skulde Petitionen i en Fart bringes rundt.

Spørgsmaalet er nu kun for os, om det kan anses for godt og gavnligt, naar vi i denne Tid, hvor der ellers ikke er noget ordentligt at tage fat $i$, kommer med en saadan Udtalelse af det Nordslesvigske Folk.

De vil gøre os en stor Tjeneste, naar De godhedsfuldt vil meddele mig Deres Mening.

Jeg har hidtil ikke kunnet opdrive alle de gamle Numre af »Flensburger Anzeiger« og sender derfor i Dag en mangelfuld Pakke. ${ }^{16}$ )

I Eftaraaret 18169 overtager Gustav Johannsen en ny Virksomhed, nemlig som Redaktor af "Flensborg Avis« fra 1. Okt. "Den staar saa levende for min Erindring hin Aften i Aaret 1869, da en lille Kreds af Flensborgere var samlet i C. F. Monrads Hus for at tage endelig Bestemmelse om det vovelige Skridt at begynde paa at udgive et Dagblad i det danske Sprog i den tysktalende By - skriver Overlærer Jens Langkjær i en Mindeartikel i Lolland Falsters Stiftstidende for 26. Okt. 1901. "I »den danske Tid" havde man ikke dristet sig dertil, og nu var Forholdene jo langt vanskeligere under den preussiske Valg- 
lov. Gustav Johannsen var den næstyngste Mand i’den lille Forsamling, men han tog dristig Ordet for at tilraade, at der straks skulde tages fat, skønt han vidste, at han vilde komme til at lægge Skuldre til; thi Hovedvanskeligheden ved at faa Sagen i Gang bestod netop deri, at der var saa faa personlige Kræfter til Raadighed. Rollerne maatte fordeles mellem de faa tilstedeværende. "Flensborg Avis" urkom fra 1. Okt. 1869 med Boghandler Gustav Joh annsen som Udgiver, den hidtilværende Redaktør af den dansksindede "Flensburger Anzeiger", C. A. W i ll e m o ës, som Redaktør og Fabrikant A. G. F r e ude $\mathrm{nrei}$ ch som Formand for Bladets Bestyrelse. Det væsentligste Medarbejderskab ved Bladet skulde være gratis, og vi haabede at kunne begynde med 600 Abonnenter."

Efterfølgeren, Redaktør J ens Jesse n, udtaler et Sted om Gustav Johannsens Virksomhed ved "Flensborg Avis« 1869-83, under hvilken han af de preussiske Domstole blev idømt Frihedsstraffe, saa han i 1876 tilbragte 1 Maaned, i 1878 2 Maaneder i Fængslet i Glückstadt ${ }^{17}$ ) og i 18793 Maaneder i Fæstningsarrest i Magdeburg: "Naar der i 1869 for forste Gang oprettedes et Blad paa Dansk i Flensborg, saa skyldtes dette vel ikke alene J.; men uden ham og hans store Indflydelse i det flensborgske Borgerskab vilde det næppe have været muligt at stifte Bladet og hævde det $\mathrm{i}$ den første vanskelige Tid. Oprettelsen af »Flensborg Avis« er derfor først og fremmest knyttet til Johannsens Navn. ${ }^{19}$ )

$*$

Næste Brev er først dateret 6 Aar senere, nemlig 5. Sept. 1875:

Indlagt sender jeg Ansøgningen for C. L. Brandt, idet jeg paa hans Vegne tillader mig at bede Dem om at gøre alt, for at han kan faa Hjemstedsbevis snarest muligt. Hans tilkommende Svigerfader, en af vore brave danske Folk, er meget ked af den megen Ulejlighed, der er forbunden med at faa Beviset, og jeg med; thi Folk kan slet ikke forstaa, hvorfor man gør saa mange 
Vanskeligheder lige overfor en saa afgjort dansk Undersaat, som Brandt unægtelig er.

17. Aug. 1876 [Regenburgs Svar 28. Aug.]: De har en Gang sagt til en Ven af Dem, at for mig vilde De altid gøre, hvad der stod i Deres Magt. Derfor var det ogsaa, at jeg i sin Tid tillod mig at henvende mig til Dem med Bøn om at udvirke, at jeg blev udnævnt til Kordegn i Aarhus, men da jeg ikke erholdt denne Plads, sluttede jeg, at De ikke havde formaaet at skaffe mig den. Det var heller ikke af Lyst, at jeg søgte det nævnte Embede, kun nodig vilde jeg tage herfra, da jeg har den Overbevisning, at jeg ikke godt kan undværes her. Men mine undergravede finansielle Forhold bevægede mig til at gøre et Forsøg paa at komme ud af dem.

Der kommer undertiden en vis Angst over mig, naar jeg tænker paa, at jeg har tilsat min Formue og nu sidder i Gæld. Min Kones og mine mange Borns Fremtid faar mig undertiden til at tænke, at jeg ikke burde have gjort, hvad jeg i Troen paa en snarlig Forandring af vore Forhold her mente at kunne forsvare at gøre. Jeg har dog ikke alene brugt min egen Formue, men ogsaa mine bedste Venners Understottelse har jeg benyttet, og derfor er jeg netop i Gæld hos disse. - Kunde De ikke hjælpe mig til et Laan? Jeg ved nok, at De ikke er nogen Pengemand, med jeg ved ogsaa, at jeg ikke kender andre, som jeg kunde gaa til med en saadan Anmodning. I Haab om, at De vil kunne formaa en patriotisk Pengemand til at laane mig den Sum, henvender jeg mig til Dem og haaber, at De ikke vil slaa Haanden af mig.

De folgende 3 Breve fra 1889 findes trykt i Sønderjydske Aarbøger 1936, S. 232-33, og overspringes her, da de væsentlig kun indeholder Bemærkninger om Bøger, som Regenburg skulde sende Gustav Johannsen til hans Rigsdagsvirksomhed. ${ }^{19}$ ) 


\section{Noter.}

1) Sønderj. Aarbøger 1939, S. 1 ff.

2) Enkelte af Brevene har jeg allerede offentliggjort i Sønderj. Aarb. 1936, S. $231 \mathrm{ff}$.

3) S. Aarb. 1937 , S. 168 ff., 1938, S. 111 ff. og S. 306 ff.

4) H. F. Petersen: Fra sydlesvigske Præstegaarde, 1938, S. 187.

5) S. Aarb. 1902, S. 109 f. og 118 f.

6) Alexandra Johannsen: G. J.s Barndom (S. Aarb. 1914, S. 99-158).

7) S. Aarb. 1914, S. 141.

8) H. F. Petersen: Fra sydislesvigske Præstegaarde, S. 187.

O) S. Aarb. 1902, S. 110.

10) Sprogforeningens Almanak for 1903, S. $83 \mathrm{f}$.

11) H. P. Hanssen anf. Sted, S. 84.

12) General Manteuffels Tale i Flenshorg inrleholılt bl. a. Ytringen: "Hver syv Fod Jord vil jeg dække med min Krop, fur jeg afstaar den«. (M. Mackeprang: Nordslesvig 1864-1909, Kbh. 1910, S. 15).

13) Jeg: Hr. Borgmester! Jeg er Privatlærer osv. - Borgmesteren: Er De Seminarist? - Jeg: Ja, - B.: Hvor er I)e føalt? - J.: I Angel. - B.: Ved hvilket Institut virker De? - J.: Jeg virker ikke ved noget Institut. - B.: Da De personlig kommer til mig, skal De ogsaa have mit personlige Raad: Tag Deres Ansogning tilbage, for derved afskærer De Dem alle Veje til Befordring. Trang til en dansk Privatskole i clenne tyske By eksisterer slet ikke, der findes Midler til at lare det danske Sprog i Overflod, og De mat og skal vide, at det kun er en politisk Demonstration, naar Folk forlanger clansk Undervisning. - J.: Tillader De, Hr. Borgmester, fra min Side er det kun et Eksistenssporgsmaal og ingen politisk Demonstration. - B. (heftig): Naar De ikke betragter det som en politisk Iemonstration og alligevel som født tysk Mand rækker Haanden til noget saadant, saa har De mistet min Agtelse og vil tabe enhver Respekt. - J.: Hr. Borgmester, jeg har aldrig larlet mig henytte som et dollt Redskab og kender heller ikke til, at jeg nogetsteds har mistet Folks Respekt. - B.: Ja, hvis De tilhorer navnte Parti, er det noget ganske andet. Deres Ansogning gaar saa Forretningsvejen, og jeg er slet ikke tilhojelig til at modvirke den; thi sadanne Demonstrationer skal man ikke helt staa imod. Men, unge Mand! betærik Deres eget Vel og træk endnu Anssgningen tilhage, ellers er enhver Vej til Befordring afskaaret for bestandig. - J.: Jeg mener at forstaa Deres Raad, men maa bemærke, at det synes mig liclet nyttigt at hefslge Borgmesterens Raad, for allerede i Langballe mener jeg at have erfaret, at man ikke vil have mig; Muligheden for Befordring har jeg vist allerede forspildt. - B.: Nej, det var den Gang, men her vil det hlive til Deres Skade; thi selvom De ogsaa i Dag fik en Privatskole fuld af danske Børn, vilde den vare tom om et Aar, og her $i$ en tysk By vil der om et Aar ikke mere eksistere nogen dansk Skole. Eniluu en Gang, tag Ansøgningen tillage og lad Dem overhovedet ikke bruge af næunte Parti, naar De ikke tilhører det. - J.: Hr. Borgmester, som sagt, jeg lader nig ikke bruge; jeg tilhører selv Partiet og anser inin Ansøgning for berettiget. - B.: Nuvel, saa gaar Deres Ansøgning den forretningsmæssige Vej, og det er ikke umuligt, at De faar Tilladelsen. Farvel!

og Konge!

$\left.{ }^{14}\right)$ Allerduchlauchtigste, Allerstormagtigste, Allernaadigste Herre

Den berømmelige preuss. Armés sidst vunine Sejre og Resultater har hos Hertugdemmernes Befolkning bekraftet Beviclstheden om, at den preuss. Stats Styrke, som for 2 Aar siden her mod Nord gen- 
nem herlige Sejre besegledle Landets Befrielse, er stor nok til ved hurtig, omend dyrekøht Kamp a hidfore det store Værk, der hedder Tysklands Enhed og politiske Genfurlelse. Kronen paa denne Kamp vil ogsaa bringe dette Land, hvis største By vi repræsenterer, Afslutningen paa de hidtidige provisoriske Tilstande og sikre os den varige Beskyttelse fra en Stat og en Hær, som i de sidste Dage atter har hevist, at Konge, Hær og Folk er sig Frederik den Stores Stats høje Mission bevidst og ejer Styrke til at opfylde denne Mission.

Flensborg Bys Magistrat udtaler kun, hvad Tusinder her føler, at den allerunderdanigst beder Leres Majestæt naadigst at modtage dens Lykønskning til dlen preuss. Armés nyeste Sejre.

Flensborg, 4. Juli 1866 .

Allerunderclanigst.

Bong-Schmidt. Funke.

Henningsen, Petersen, Jensen, Knuth, Tiedemann, Brinkmann.

15) Erklæringen har følgende Ordlyd: I en til Hs, Maj. Kongen af Preussen under 4, ds. rettet Lykønskningsadresse har Magistraten her i Byen betegnet den voldsomme Losrivelse for to Aar siden af Hertugdømmet Slesvig fra Danmark som "e n B ef riels e og derefter udtalt det Ønske, at Landets Forhold maatte blive endeligt ordnede saaledes, at det kom til at sta under Preussens nizgtige Beskyttelse.

I Anledning af disse Idtalelser, som Magistraten ikke har ind. skrænket sig til at fremkomme med alene i sit eget Navn, men som den tillige har anmasset sig at gore , Starlen Flenshorors Narn, faler vi undertegnede Borgere i Flenshorg os paa det starkeste opforirecie til at afgive følgende Erklæring:

Saa længe vi stod unrler den ranske Konge, ansaa vi det som vor sturste Ere og vor hedste Stolthed at vere vor Konge og vort elskede Fadreland Janmark tro og inderligt hengiven, og vi priste os lykkelige ved dette Fædreland.

Derfor kan vi umulig betragte vor Løsrivelse fra dette vort gamle Fadreland som en Befrielse. Heller ikke kan vi paa nogen Maade dele Ønsket om, at vort Lands Forhold maa blive endelig ordnede saaledes, at vi kom til at staa under Preussen. Trærtimod vilde vi betragte en saadan Løsning som den største Illykke for vor Stad, ligesom for hele Landet. Med vor inderlige Kærlighed til vort gamle Fædreland staar vi ikke alene. Tværtimod er det vor inderligste Overbevisning, at et overordent $\mathrm{ligt}$ stort Flertal af vore Medborgere er opfyldt af samme Tænkemaade som vi, deler vort Syn paa Fortiden og vore inderlige Onsker og Forhaabninger med Hensyn til Fremtiden. Skulde det engang, hvad vi levende onsker, komme til en almindelig Afstemning, vilde Sandheden af denne Paastand paa det mest slaaende blive stadfæstet. Men under vore nuværende Herrer er enhver fri Ytring af vor Tænkemaade forbudt os under de haardeste straffe. Medens man luder os i Ro fortsætte vort borgerlige Erhverv, gar man alt for at forpine og kue vort aandelige Liv.

Flensborg i Juli 1866. Inderskrevet af: Peter Marquardsen, N. Nielsen, J. F. W. Partsch, N. N. Schmilt, H. Jensen, Georg Hildebrandt (for den søndre Del af Byen) og T. C. Tüchsen, J, Plaetner, C. Christensen, C. Schmidt, N. L. Toft og Hans (.. Jacol)sen (for den nordre Del af Byen). 
16) Paa Brevhoveclet

$$
\text { Bog-, Kunst-, Fotografi- og Papirhandel. }
$$

for "Nye danske Brandforsikkringsseìskab« i Kjøbenhavn; Agentur

for Livrente- og Livsforsikringsselskabet "European" i London.

17) Gustav Johannsens Dagbog fra Fængslet i Glückstadt i 1876 er aftrykt i Sprogforeningens Almanak for 1930, S. 69-78.

14) Franz von Jessen: Haandbog i det nordslesvigske Spørgsmaals Historie, 1901, S. 579.

19) Denne. der strakte sig fra 1881 til hans Dod rlen 25. Okt. 1901, er skildret af H. P. Hanssens-Nørremølle i S. Aarb. 1902, S. 264-297. 